\title{
Temporary Assistance for Needy Families and the Black-White Child Poverty Gap in the United States
}

\author{
Zachary Parolin \\ Columbia University \\ Pre-print of article forthcoming at Socio-Economic Review \\ https://doi.org/10.1093/ser/mwz025
}

\begin{abstract}
Black children in the United States are more than twice as likely as white children to live in poverty. While past research has primarily attributed this phenomenon to the family structure of black children, this paper investigates how state-level heterogeneity in social assistance programs contributes to the black-white child poverty gap. I find that racial inequities in states' administration of the Temporary Assistance for Needy Families (TANF) program contributed to the impoverishment of approximately 256,000 black children per year from 2012-2014. State-year panel data demonstrates that states with larger percentages of black residents are less likely to prioritize the 'provision of cash assistance' but more likely to allocate funds toward the 'discouragement of lone motherhood.' Neutralizing inequities in states' TANF spending priorities would reduce the black-white child poverty gap by up to 15 percent - comparable to the reduction effect of moving all children in single-mother households to two-parent households.
\end{abstract}

SER Keywords: poverty, welfare state, social policy, stratification, family

JEL Classification: I32 (Measurement and Analysis of Poverty), I38 (Provision and Effects of Welfare Programs), H75 (State and Local Government: Health; Education; Welfare; Public Pensions) 


\section{Introduction}

Black children in the United States have remained more than twice as likely as white children to live in poverty since at least the early 1960s, the time when reliable household income data became available (Patten and Krogstad 2015). To explain this phenomenon, the dominant perspective in poverty research tends to focus on the family structure of black families (Fagan and Johnson 2001, Lichter, Qian and Crowley 2006, Sawhill and Thomas 2002, Sawhill 2014). As far back as 1965, Daniel Patrick Moynihan (1965:29) lamented in "The Negro Family: The Case for National Action" that the rise of single motherhood among black families "seriously retards the progress of the group as a whole." In more recent decades, lone motherhood has been deemed "a new American dilemma" (Garfinkel and McLanahan 1986) while "increasing marriage" has emerged as a solution toward closing the black-white child poverty gap (Fagan and Johnson 2001).

Sympathetic to this viewpoint, policymakers replaced Aid to Families with Dependent Children, a cash assistance program for low-income families, with the Temporary Assistance for Needy Families (TANF) program in 1996, explicitly listing the prevention of "out-ofwedlock pregnancies" and "maintenance of two-parent families" as two of the program's four programmatic purposes (Falk 2014). Spending authority over TANF funds was decentralized to state governments under the belief that the 50 states, rather than the federal government, were better equipped to achieve the program's aims.

Though this decentralization and emphasis on family structure were designed, at least implicitly, to improve the relative position of black children (Brown 2013a, Roberts 2004, Schram, Soss and Fording 2003), I hypothesize that the broad discretion given to states in determining how to allocate their social assistance funds instead contributes to the blackwhite child poverty gap. Specifically, I investigate the extent to which racial bias in states' TANF spending priorities explains racial differences in child poverty, and whether this 
variance in TANF spending is more consequential than family structure in shaping the relative likelihood that a black child lives in poverty.

The analysis of this hypothesis proceeds in three stages. First, I develop a typology for classifying cross-state differences in TANF spending priorities. Since the program's implementation, states have been granted broad discretion in deciding how to allocate TANF resources, so long as the programs or policies funded can be deemed to serve one of four purposes: (1) the provision of cash assistance, (2) the promotion of "job preparation, work, and marriage," (3) the prevention of "out-of-wedlock pregnancies," and (4) the "formation and maintenance of two-parent families."

Research on state heterogeneity in TANF has narrowed in almost exclusively on the first of these four purposes, highlighting regional differences in TANF cash benefit levels (Hahn et al. 2017, Johnson 2001) or barriers to the receipt of cash assistance (Soss et al. 2001, Soss, Fording and Schram 2011). This strict focus on cash assistance, however, misses more than three-fourths of the program's expenditures: in 2014, the average state allocated only 22.6 percent of its budget toward the provision of cash assistance (Center on Budget \& Policy Priorities 2015). In its place, states allocated TANF resources to fund a wide range of programs and policies, including childcare subsidies, Alternative to Abortion programs, dental assistance, foster care services, student textbook subsidies, grants to private foundations, 'compulsive gambler' assistance, and more. ${ }^{1}$ Classifying and conceptualizing the full scope of policies and programs toward which states $d o$ allocate their TANF funds serves as the starting point to understanding the relationship between states' racial composition and their relative TANF spending priorities.

\footnotetext{
${ }^{1}$ This list of spending allocations is derived directly from state reports submitted to the U.S. Administration on Children \& Families. Details and sourcing for each of the examples cited are outlined in Appendix A.
} 
The second and third stages investigate, respectively, the determinants of states' TANF spending priorities and the consequences of state-level heterogeneity for the black-white child poverty gap. In doing so, the paper broadens the scholarship on federalism, race, and child poverty in three main ways.

First, I add to the long tradition in comparative policy research of classifying differences in policy priorities across welfare states to explain heterogeneous social outcomes. Utilizing state spending reports and legislative documents, I identify four conceptually distinct TANF spending priorities to clarify the different mechanisms of social support that states offer to low-income families.

Second, I improve on the analytical techniques of prior studies to provide a direct estimate of the extent to which the percentage of black residents within a state influences how that state will allocate its TANF resources. Using state-year panel data from 1997 to 2014, I apply a 'within-between' random effects model to decompose the effect of changes in demographic, political, and economic determinants within states versus differences between states in predicting states' TANF spending priorities.

Finally, I evaluate the consequences of the potential racial bias in TANF spending priorities on the black-white child poverty gap. This is the first attempt, to my knowledge, to directly link the racial bias embedded into state-level social assistance packages to racialized differences in child poverty outcomes. In doing so, I estimate that a modest move toward racial neutrality in states' governance of TANF would increase annual spending on cash assistance by about $\$ 3.2$ billion and reduce the black-white child poverty gap by up to 15 percent over the years 2012 to 2014. In contrast, moving all children in single-parent households to two-parent households would lead to an estimated 10 percent reduction in the black-white gap. These results suggest that family structure is insufficient as an explanation for racial differences in child poverty. Instead, inequity in welfare state institutions - 
specifically, states' administration of the TANF program - must be at the core of analyses of black-white child poverty comparisons.

\section{Background \& Theory}

\section{STATES \& SOCIAL POLICY}

American poverty and inequality research is most often conducted at the national level; increasingly, however, researchers have sought to understand the influence of state policy decisions on regional and racial variations in poverty and wellbeing.

This line of research has demonstrated that state policy decisions with respect to tax, benefit, and regulatory schemes often manifest into regionally stratified social support systems for low-income households. Differences in the progressivity of states' tax systems, for example, have been tied to a range of wellbeing indicators among poor families (Newman and O'Brien 2011, O'Brien 2017). Similarly, state-level implementation of anti-union regulation has been associated with higher levels of poverty among working households (Brady, Baker and Finnigan 2013). These examples suggest it is increasingly relevant to consider the United States as composed of 50 different welfare systems rather than as a single, homogenous institution.

By nature of this heterogeneity, states and state governments can be understood as political institutions that foster inequities in the access or generosity of social support. This appears to be especially true with respect to TANF, a program designed explicitly to foster state-level divergence. Despite two decades of research on the program, cross-state differences in how states use TANF funds to govern low-income families are rarely conceptualized. The bulk of research on the program's variation focuses on cash benefit levels and barriers to the receipt of cash assistance; absent, however, is a clear understanding of the extent to which states prioritize TANF's other purposes, such as the promotion of 
employment or the maintenance of two-parent families, and how the relative prioritization of these alternative purposes may influence the wellbeing of low-income families.

Conceptualizing and measuring the different ways in which states allocate their TANF resources is thus a necessary starting point toward understanding the potential consequences of different spending priorities on child poverty outcomes.

In conceptualizing differences in TANF priorities across states, I follow a tradition within comparative social policy research of classifying welfare states according to shared redistributive or stratifying features (Bambra 2007, Esping-Andersen 1990, Meyers, Gornick and Peck 2001). I rely on states' annual TANF budgets to classify differences in states' utilization of the TANF program. As the level of TANF budgets within states are relatively stable over time, the share of a state's budget allocated to each of the four categories can appropriately be extracted to reveal a state's relative TANF priorities in a given year and, more broadly, how states vary in the types of support offered to low-income families. I assess how states spend the sum of their federally-funded 'block grant' and the state Maintenance of Effort (MOE) requirement (a certain level of funds that states must invest into the program in order to receive federal support).

In reviewing the spending data, I identify four distinct conceptual spending priorities based on (a) the particular social outcome that the spending aims to influence, (b) the programs or policy tools implemented to achieve the desired outcome, and (c) the implications for the financial security of low-income families. As detailed in Table 1, three of the spending priorities identified align with the core purposes explicitly listed in the TANF legislation: the provision of cash assistance, the facilitation of employment, and the discouragement of lone motherhood. A fourth pattern observed is the utilization of TANF funds to fulfill services that are only tangentially related to the program's core purposes such as the funding of child protective services, foster care, and mental health services. 
Table 1: Overview of TANF Spending Priorities

\begin{tabular}{|l|l|l|}
\hline $\begin{array}{l}\text { TANF } \\
\text { Spending } \\
\text { Category }\end{array}$ & $\begin{array}{l}\text { TANF's Legislative Goals } \\
\text { Addressed }\end{array}$ & Formal TANF Reporting Categories \\
\hline $\begin{array}{l}\text { Cash Assistance } \\
\text { cash })\end{array}$ & $\begin{array}{l}\text { (1) provide assistance to needy } \\
\text { families so that children may be } \\
\text { cared for in their own homes or } \\
\text { in the homes of relatives }\end{array}$ & Basic Assistance \\
\hline $\begin{array}{l}\text { Facilitation and } \\
\text { Incentivization } \\
\text { of Employment } \\
\text { work) }\end{array}$ & $\begin{array}{l}\text { (2) end the dependence of needy } \\
\text { parents on government benefits } \\
\text { by promoting job preparation, } \\
\text { work, and marriage }\end{array}$ & $\begin{array}{l}\text { Work Subsidies; Education \& Training; Other } \\
\text { Work Activities/Expenses; Transportation } \\
\text { Assistance; Transporation Nonassistance: Job } \\
\text { Access; Other Transporation Nonassistance; } \\
\text { Individual Development Accounts; Child Care } \\
\text { Assistance; Child Care Nonassistance; } \\
\text { Transferred to Child Care \& Development } \\
\text { Fund; Refundable Earned Income Tax Credit; } \\
\text { Other Refundable Tax Credits }\end{array}$ \\
\hline $\begin{array}{l}\text { Discouragement } \\
\text { of Lone } \\
\begin{array}{l}\text { Motherhood } \\
\text { family) }\end{array}\end{array}$ & $\begin{array}{l}\text { (3) prevent and reduce the } \\
\text { incidence of out-of-wedlock } \\
\text { pregnancies and establish annual } \\
\text { numerical goals for preventing } \\
\text { and reducing the incidence of } \\
\text { these pregnancies; (4) encourage } \\
\text { the formation and maintenance } \\
\text { of two-parent families }\end{array}$ & $\begin{array}{l}\text { Pregnancy Prevention; Two-Parent Family } \\
\text { Formation \& Maintenance }\end{array}$ \\
$\begin{array}{l}\text { None } \\
\text { (other) }\end{array}$ & $\begin{array}{l}\text { Assistance Authorized Under Prior Law } \\
\text { (AUPL); } \\
\text { Nonassistance AUPL; Nonassistance Other; } \\
\text { Transfers to Social Services Block Grant }\end{array}$ \\
\hline
\end{tabular}

Note: Administrative costs, systems management, and some short-term benefits, such as burial assistance and diversion programs, are not included into these categorizations. States spent an average of approximately 10 percent of their TANF budgets on these unlisted items per year.

Each of the four spending priorities identified in Table 1 are now briefly described:

Provision of Cash Assistance: The provision of cash assistance aligns with the first listed purpose of TANF: to provide direct assistance to low-income families. Of the four spending priorities, it has the most direct redistributive effect on a household's income and poverty status. Cash assistance from TANF is targeted at lower-income families and mechanically increases household income; as such, it directly improves a family's consumption capabilities and, in many cases, ensures that a family is not left without any 
source of market or transfer income. In 2014, states allocated an average of 22.6 percent of their TANF budgets toward the provision of cash assistance. South Dakota led all states in allocating 61.2 percent of its budget toward this purpose; on the other end of the spectrum, the state of Illinois allocated only 6.4 percent toward cash support.

Facilitation and Incentivization of Employment: This spending priority reflects 12 spending categories within TANF spending data that each act to make employment more accessible and/or more attractive for low-income families. The primary mechanisms to achieve this end include childcare assistance, transportation support, wage subsidies and income-based tax credits, and skill development through continued training or education. The facilitation of employment has the potential to affect poverty through less direct mechanisms relative to cash assistance: with childcare subsidies, transportation assistance, and education support, work becomes more accessible. With increases to income-based refundable tax credits, even low-wage work leads to higher take-home pay. In 2014, Nebraska spent nearly 70 percent of its TANF budget on efforts to facilitate or incentivize employment; Nevada, conversely, allocated 2.7 percent of its budget toward this purpose - the least of all states.

Discouragement of Lone Motherhood: A spending priority that has emerged in certain states within the last decade is the discouragement of lone motherhood. This category consists of state-funded initiatives to achieve one or both of TANF's aims to reduce out-of-wedlock pregnancies or to encourage the promotion and maintenance of two-parent families. In practice, the allocation of TANF funds toward these aims tends to come in the form of statelevel efforts to provide family planning services (such as Louisiana's 'Alternative to Abortion' program), create "responsible fatherhood" initiatives that aim to enhance the employability of noncustodial fathers (Germanis 2015, Schott, Pavetti and Floyd 2015, Ziliak 2015), and to promote sex education and abstinence curricula within school - such as Mississippi’s "abstinence-till-marriage” curriculum, which "teaches the social, psychological 
and physical effects of engaging in sexual activities" (State of Mississippi 2010:6). To reduce the likelihood of poverty, such initiatives would presumably need to achieve their aim of encouraging marriage or preventing single women from bearing children. Evaluations of states' initiatives to promote marriage, however, have demonstrated "little effect on indicators of coparenting, parenting, or child well-being" and do not result in more couples staying together (Lundquist et al. 2014). In 2014, Arkansas spent 66.3 percent of its TANF budget on efforts to discourage lone parenthood, while 14 states did not invest any TANF funds toward this purpose.

Other Services: The final spending priority derived from the data is a category of policies that allow states to eschew the core purposes of TANF and instead allocate the program's funds toward a range of tangentially-related services that, in some cases, would otherwise be funded through general state revenues. These types of services include adoption services and foster care assistance, licensing of childcare centers, financial aid for university students, family health and violence services, family dental assistance, student textbook subsidies, drug court programs, grants to private foundations, and more (Germanis (2015), Richie (2012); see Appendix A for more). In 2014, South Carolina led the way in transferring TANF funds toward 'other services'; the state allocated more than 77 percent of its budget toward these ends. The mean value across all states in 2014 was 27 percent - more than four percentage points higher than the average allocation toward cash assistance.

Figure 1 depicts changes in average spending priorities over time. The provision of cash assistance has decreased steadily for the average state since 1997, while the other three priorities have received increasing levels of funding. The relative allocations for each state from 2012 to 2014 are provided in in the supplementary appendix (Table S1). 
Figure 1: Unweighted Mean Value of States' TANF Spending Priorities by Year (1997 to 2014)

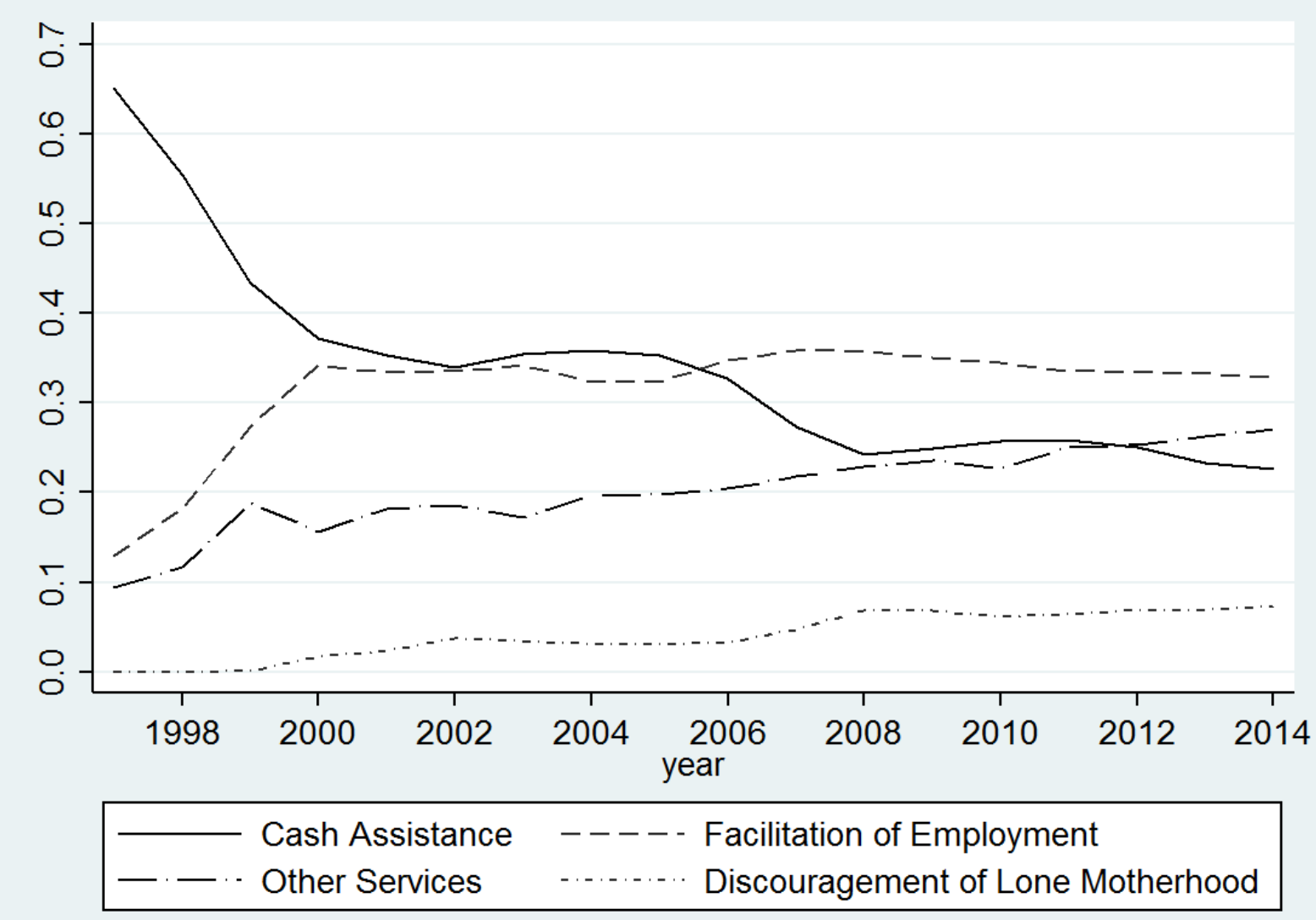

Note: See Table 1 for overview of spending categories. For data on spending priorities for each of the 50 states (and DC) from 2012 to 2014, see the Supplemental Appendix (Table S1).

The conceptualization of these four spending priorities offers a more complete understanding of how states utilize the TANF program and how they vary in the types of assistance provided to low-income families. With the spending priorities identified, I now turn toward understanding the sources and consequences of these cross-state differences.

\section{RACIALIZATION OF SOCIAL POLICY}

Comparative welfare state literature has largely focused on the role of class-based political action in explaining variation in the size or generosity of welfare states across time and place. Power resources theorists, for example, have demonstrated that the mobilization of unions and working-class voters can, through the election of a left-leaning political party, 
contribute to stronger redistributive policies and more egalitarian wage distributions (Brady 2009, Korpi 1983, Stephens 1979).

Power resources theory has less often been applied to variation in social policies across the 50 states. Applied to the context of cross-state differences in TANF allocations, a straightforward extension of the theory might suggest that larger unions and a greater share of elected Democrats would tilt a state's TANF spending priorities toward cash assistance or employment support rather than efforts to influence family formation. Indeed, electing more Democrats has been linked to more accessible TANF benefits (Fellowes and Rowe 2004). Meanwhile, higher union density appears to be correlated with higher minimum wages and TANF benefit levels (Brady, Baker and Finnigan 2013). Still, a focus exclusively on class politics to explain states' TANF spending overlooks what might be a more relevant source of cross-state variation in social policy: racial composition and racialized attitudes toward redistribution. As Brady (2009:117) acknowledges in his book advancing a refined version of power resources theory, the "most important limitation" of the theory is its underappreciation of the salience of race and gender in shaping social policies. Indeed, Mettler (1998) demonstrates that as far back as the New Deal, race and gender have been central to the implementation of states' social and labor market policies. Quadagno (1998:250), who has chronicled the role of race in shaping American welfare states, similarly writes that the literature's “emphasis on class struggle ... has led class analyses to ignore a defining feature of social provision: its organization around race and gender." A rich history of evidence exists to suggest race, rather than class, might emerge as a more consequential source of states' TANF allocations (Alesina, Glaeser and Sacerdote 2001, Brown 2013a, Brown 2013b, Brown and Best 2017, Fox 2004, Gilens 1999, Johnson 2001, Quadagno 1994, Schram, Soss and Fording 2003).

At the individual level, evidence suggests that whites are more likely to perceive black 
Americans as being lazy or undeserving (Katz 1990). Gilens (1999), for example, finds evidence that white Americans tend to believe that black Americans' relative disadvantage is due to a lack of effort. These perceptions subsequently shape individual attitudes toward the welfare state. Krimmel and Rader (2017:5) find, for example, that symbolic racism - defined as "the belief that Blacks get more assistance than they deserve from government" - is four times stronger than an individual's income in predicting negative attitudes toward redistribution.

Importantly, these attitudes do not appear to span across all racial minorities, but are instead specific toward black residents. In a study of whites' attitudes toward social assistance, for example, Fox (2004) finds that a larger share of Latinos in a state is associated with more favorable attitudes among whites toward the work effort of Latino residents. As Fox (2004:595) summarizes, "[t]he more Latinos in a state or county, the more positive whites feel toward Latinos. Conversely, the more blacks in a state or county, the more negative whites feel toward blacks." This mirrors findings from Taylor (1998), who suggests that proximity to Latinos does not increase white racial animosity in the same way that it does for African-Americans. Brown (2013b:290) unpacks these findings further, demonstrating that differing public attitudes toward documented ("more worthy") versus undocumented ("undeserving") Hispanics help to explain why "the relationship between race and welfare policy is less predictable for Hispanics than for Blacks." Building on this evidence, I focus primarily on how the share of black residents in a state shapes TANF spending priorities.

With respect to the provision of cash assistance through TANF (or AFDC), prior research has connected the prevalence of the black population within a state to lower average levels of benefit generosity (Brown and Best 2017, Johnson 2001), stricter conditionality requirements in determining eligibility for cash assistance (Soss et al. 2001), as well as states' tendencies to devolve TANF authority to the local level (Soss, Fording and Schram 2008). 
Due to the exclusive focus of prior studies on cash assistance, however, it remains unclear how states' racial compositions interact with the other three TANF spending priorities. If states with larger shares of black residents spend a smaller share of TANF funds on cash assistance, do they then allocate the preserved funds toward the facilitation of employment, the discouragement of lone motherhood, or other tangentially-related services? Such distinctions are relevant: on a theoretical front, they broaden our understanding of how perceptions of black families interact with the types of 'social assistance' that states prioritize. On a functional level, states' relative allocations toward these alternative TANF spending priorities may be likely to affect child poverty outcomes. We might find, for example, that greater investment in the facilitation of employment, such as the provision of child care support or transportation assistance, is more effective at improving a household's financial wellbeing than, say, the provision of abstinence-only sex education courses.

Building off the empirical findings linking perceptions of black Americans to unequal social assistance policies, I hypothesize that a greater share of black residents in a state will be associated with lower prioritization of the provision of cash assistance. Given the centrality of family structure in discourse regarding black poverty (Fagan and Johnson 2001, Moynihan 1965, Rector 2012), as well as the observed fact that black children are likelier than white children to live in single-parent households, I also expect that the share of black residents in a state will be associated with greater prioritization of the 'discouragement of single motherhood.' Moreover, given perceptions among whites that black Americans have lower levels of work ethic, I expect a greater prioritization of the 'facilitation and incentivization of employment' spending priority in states with a larger black population. Less theoretical justification exists for linking racial composition to prioritization of the 'other services' spending priority; thus, I test for a possible relationship in my empirical analysis, but abstain from a priori speculation. 


\section{RACIAL DIFFERENCES IN CHILD POVERTY}

In prior research that links racial composition to TANF/AFDC cash assistance, it remains unclear whether the observed relationship between race and policy generosity manifests into racial differences in child poverty outcomes. Thus, the studies offer incomplete empirical insight into the role of social assistance in shaping the black-white child poverty gap.

For racial biases in states' TANF spending priorities affect the black-white child poverty gap, two underlying premises must hold true: first, the four TANF spending priorities should differentially affect a household's likelihood of poverty; and second, certain spending priorities should affect the likelihood of poverty among black children more so than white children. As outlined previously, the four TANF spending priorities are likely to differentially shape poverty outcomes: the provision of cash assistance is the most direct mechanism for increasing a household's income, while the facilitation of employment and discouragement of single motherhood operate through the mechanisms of job attainment and family structure, respectively.

Why, though, might differences in states' prioritizations of these four categories affect the likelihood of poverty among black children more so than white children? I propose three different scenarios in which these differences in TANF priorities can affect the relative likelihood that a black child lives in poverty.

First, it may be the case that black children are likelier to live in poverty in part because they happen to live in states that give less priority to the 'provision of cash assistance' or 'facilitation of employment' (a composition effect). If this is accurate, then we should expect the relationship between poverty and a black child's race to weaken after we account for states' TANF spending priorities. This would imply that TANF is the mechanism through which race is associated with poverty. 
Second, TANF spending priorities may have an intervening effect on the relationship of race and poverty (a moderation effect). If so, then we would find that TANF spending priorities directly moderate the relationship between a black child's race and the likelihood of poverty. This could occur, for example, if the average black children faces an elevated risk of poverty relative to a white child. In this scenario, an increase in a states' prioritization of cash assistance may more strongly affect a black child's risk of poverty. A moderation effect may be identified in conjunction with, or distinct from, the composition effect identified above.

Finally, we may find that racial bias in states' TANF spending priorities has no racialized effects on child poverty outcomes. As detailed, TANF budgets have declined in real terms across all states, and nearly all states now allocate less than half of their budgets toward the provision of cash assistance — the spending priority that is likely to have the most direct effect on poverty outcomes. Furthermore, the estimated racial bias in states' spending priorities may be too small, or perhaps even non-existent, leading to no observable effect on the black-white child poverty gap. If this is the case, TANF may be racialized in source, but without any observable consequence on racial differences in child poverty.

\section{Data \& Methods}

The empirical analysis proceeds in two stages. The first applies state-year panel data to measure the determinants of states' TANF spending priorities. If the racial composition of a state proves to be a notable determinant, the second stage then tests whether racial inequity in states' TANF spending priorities influences the black-white child poverty gap.

\section{DETERMINANTS OF TANF SPENDING PRIORITIES}

In evaluating the determinants of states' TANF spending priorities, I apply panel data covering the 50 states and Washington, D.C. from the years 1997 to 2014 (a total of 918 state- 
years). ${ }^{2}$ These time points mark, respectively, the first year in which TANF was implemented in all states and the most recent year for which data on all variables (detailed below) is available. I estimate four separate models: one for each of the four TANF spending priorities identified in the prior section. The dependent variable in the estimations is the percentage of a state's TANF budget allocated toward the spending priority (e.g. 'provision of cash assistance') in the respective year.

The primary explanatory variable is the percentage of black residents within the state in the respective year. I include a large collection of control variables to account for other potential demographic, political, and/or economic determinants of states' TANF spending priorities. The data sources for each of these controls is detailed in Appendix B. Demographic controls include the share of Hispanic residents within the state-year, as well as the share of Asian residents, share of other (non-white, black, Hispanic or Asian) race, and the share of children living in lone-parent households. Political controls include the share of a state's legislature composed of Democrats, the union density within the state, and a binary dummy variable to indicate whether the governor of the state is a Democrat. ${ }^{3}$ Finally, economic predictors include the state's unemployment rate, the employment rate of single parents, and the state's GDP per capita. To account for differences in the level of states' TANF budget, I control for states' total TANF budget size divided by the number of children in the state. In sensitivity checks, I add a dummy variable to indicate whether the state was one of the 11 Confederate states in the American South. ${ }^{4}$ Only one result is partially affected in the

\footnotetext{
${ }^{2}$ As D.C. administers its own TANF program and is more populous than some formally-recognized states, I include it in this analysis. Removing it, however, has no substantive effect on the findings. ${ }^{3}$ Nebraska features a unicameral legislature; thus, I use the proportion of Democrats in its Congressional delegation as a substitute for the share in its state delegation.

${ }^{4}$ I exclude the 'Confederate state' dummy from my primary analysis, as such distinction is arguably unimportant for this analysis: if states with more black children receive a different allocation of TANF funds, and if this racially-biased allocation increases the likelihood of poverty among black children, then such patterns are significant to our understanding of poverty even if the
} 
sensitivity check, which I highlight in the 'Findings' section below.

To test the effect of racial composition on a state's TANF spending priorities, I apply a 'within-between' random-effects model. This allows for simultaneous interpretation of the effects of within-state determinants, as one could produce using a fixed effects (FE) model, and the between-state determinants (Allison 2009, Bartels 2009, Bell and Jones 2014). A standard FE model is not appropriate for the analysis, as I am primarily concerned with the variability in TANF spending priorities that occurs across states rather than within. Given this, a traditional random effects (RE) estimation is superior to the FE, but still suffers from flaws that may impede proper interpretation of the findings. In particular, a RE model confounds the within- and between-case effects in the coefficients that it produces (Bartels, 2009). Specifically, a standard RE model might find that, say, the percentage of black residents in a state is associated with a greater prioritization of the 'discouragement of lone parenthood,' but it does not disentangle whether the effect occurs due to changes within states in the share of black residents over time or differences across states, or both. The 'withinbetween' model applied here separates and explicitly evaluates these different effects for each of the variables included in the analysis.

The model applied in this analysis is specified as follows:

$$
Y_{t j}=\beta_{0}+\beta_{1} X_{t j}^{w}+\beta_{2} \bar{X}_{j}+\delta_{t}+u_{j}+e_{t j}
$$

where $t$ indexes year and $j$ indexes state. The outcome variable, $Y$, represents the share of a state's TANF budget allocated toward the particular spending priority of interest. $X_{t j}^{w}$ is the within-state operationalization of a series of predictors, and is equivalent to the value of state-year predictor minus the state-specific mean of the predictor over all years $\left(X_{t j}^{w}=X_{t j}-\right.$ $\left.\bar{X}_{j}\right) . \beta_{1}$ thus represents the within-state effects of the predictor variable, empirically similar racial bias occurs primarily in Southern states. 
to the coefficient that a FE model would produce for the same set of years, states, and predictors. ${ }^{5} \beta_{2}$ represents the between-state effects (the cross-sectional component) of the predictors, which are operationalized here as their state-specific means across all years. A year dummy $\left(\delta_{t}\right)$ captures the potential effect of unobserved time-variant factors that may influence states' TANF allocations. The error terms are separated into within-state $\left(e_{t j}\right)$ and between-state $\left(u_{j}\right)$ components. Robust standard errors are applied and are clustered at the state level.

\section{EFFECTS OF TANF SPENDING PRIORITIES ON CHILD POVERTY}

If the results reveal that the percentage of black residents does, indeed, shape the extent to which a state prioritizes the provision of cash assistance or other allocations, I then proceed to the second stage of the analysis: understanding whether the estimated racial inequity in states' TANF spending priorities influences the black-white child poverty gap.

I estimate a series of multi-level linear probability models (LPM) of child poverty. The sample is limited to dependent children under age 18 with a binary indicator of poverty status (defined below) set as the dependent variable. I choose the multi-level LPM over a logistic regression model for two primary reasons. First, the LPM provides more interpretable interaction effects than the logistic regression model; as detailed below, cross-level interactions are necessary to estimate the effects of states' TANF spending priorities on the relatively likelihood that a black child's race leads to poverty (Allison 2009, Brady, Finnigan and Hübgen 2017). As Ai and Norton (2003) detail, the magnitude and standard errors of

\footnotetext{
${ }^{5}$ In results available upon request, I perform a robustness check in which a one-year lag of the within-state component of the dependent variable is included in the models to account for dynamic effects. A cost of including the lag is the loss of the first year of data (1997), and no consensus exists on whether it should be included into this type of analysis (Allison 2009). The lagged analysis otherwise produces similar results as the primary analysis, but with a slightly higher estimated effect of the between-state component of states' shares of black residents.
} 
interaction terms in logistic regression models are not straightforwardly interpretable, and in fact are often interpreted improperly in nonlinear models. Second, and relatedly, the LPM is more suitable than the average marginal effects from a logistic regression for producing a counterfactual simulation of poverty outcomes - a core purpose of the analysis here (Brady, Finnigan and Hübgen 2017). ${ }^{6}$ As a robustness check, however, I provide estimates of a multilevel logistic regression model in the supplementary appendix (Table S4); the findings mirror each other.

To ensure adequate state-level sample sizes, I run the multi-level model over the three latest years in the analysis (2012 to 2014), applying year fixed effects to control for any timevariant effects on poverty that are common to all states across the three years. All children (under 18 years old) are nested in the 51 states (including D.C.). Following previous research (Blank, Danziger and Schoeni 2006, Brady, Finnigan and Hübgen 2017, Lohmann 2009, Rainwater and Smeeding 2003), the model includes the child's race, the citizenship status of the head of the child's household, the age of the head of the child's household, education status of the head, the household's employment status, family structure, and continuous variables for the number of children and the number of seniors in the household. State-level controls include the state's unemployment rate, union density, GDP per capita, the real value of the statutory minimum wage, any state supplements to the federal EITC or SSI programs, per-child TANF budget levels, and the TANF spending priorities. As in the state-year panel model, the four spending priorities are operationalized as the share of a state's TANF budget allocated toward the particular spending priority. Data sources are provided in Appendix B.

\footnotetext{
${ }^{6}$ As Wooldridge (2002:455) and Von Hippel (2015) describe, LPM can generally be used over logit models so long as heteroskedastic standard errors are accounted for, and so long as the probability of the outcome variable is not "extreme" (ex: the likelihood of committing bank fraud is rather low and, as such, would not be a good candidate for a LPM model). I apply heteroscedasticity-consistent standard errors in my estimations, and the incidence of poverty is certainly not an 'extreme' case in the U.S.
} 
As the four spending priorities are mechanically related, the risk of multicollinearity when including all into one model may plausibly be high. Indeed, a simple poverty regression that includes only the four spending priorities in the model returns a mean variance inflation factor (VIF) of 11, which climbs to 18.2 for the 'other services' variable. I thus include a maximum of three of the spending priorities in a model at one time, dropping allocations toward 'other services' in the primary models and, when explicitly evaluating the effect of 'other services,' substituting it in for the 'work' priority (the spending priority with the second highest VIF).

To evaluate the composition effect, I first run two random intercept models - one without TANF priorities included and one with them. If TANF spending priorities are the mechanisms through which race is associated with poverty, we should expect to find that including the spending priorities into the model weakens the relationship between poverty and a black child's race.

To evaluate the moderation effect, I run four random slope models with cross-level interactions on each of the respective TANF spending priorities and a black child's race. A significant interaction between race and the TANF spending priority would suggest that the respective TANF priority shapes the risk of poverty differently for black children as opposed to white children. A negative interaction between 'black' and the prioritization of cash assistance, for example, would suggest that higher levels of cash assistance reduce the relative likelihood that a black child lives in poverty. If the findings do, indeed, suggest that any of TANF spending priorities moderate the race-to-poverty relationship, I can multiply the effect size by the estimated racial bias from the state-year panel data model; the resulting value would predict the effect of racial bias in states' TANF spending priorities on the increased likelihood that a black child lives in poverty. After presenting the primary results, I describe and present several robustness checks to test the findings across different methodological 
approaches and conceptualizations of poverty.

\section{MEASURING POVERTY}

Following common practice in sociological and comparative policy literature, the poverty threshold applied in this paper is set at 50 percent of national median equivalised household income (Brady, Baker and Finnigan 2013, Brady, Finnigan and Hübgen 2017, Corak 2005, Goedemé and Rottiers 2010, Gornick and Jäntti 2016). In the supplementary appendix, I also present a robustness check in which the poverty threshold is set at 50 percent of each state's respective median household income. That the results are robust with the state-specific poverty threshold suggests that the findings are not simply a product of lower-income states having a higher share of children below 50 percent of the federal median. I do not use the U.S. Official Poverty Measure (OPM), which suffers from a number of validity and conceptual issues and has thus been avoided in recent sociological research (Citro and Michael 1995, Foster 1998, Fox et al. 2014, Parolin 2019). The income definition and poverty concept applied here take into account a comprehensive measure of post-tax, post-transfer income, identical to that used by LIS, the Cross-National Data Centre in Luxembourg. The square root equivalence scale is applied, and the equivalized disposable household income of children is used to assess a child's poverty status.

An augmented version of the CPS ASEC is used to produce these estimates. The augmentations to the data partially correct for the severe underreporting of means-tested transfers, including TANF. The augmentations use the imputations developed by The Urban Institute's TRIM3 program, which matches administrative records on TANF caseloads across states to impute benefits back into the survey data. Whereas the uncorrected CPS ASEC survey data misses about half of TANF cash transfers (Meyer and Mittag 2015), the augmented data comes much closer to capturing the full amount of cash assistance identified 
in administrative data (Parolin 2019). This is particularly important in an assessment, such as this one, that focuses on racialized child poverty outcomes: as black households are likelier than white households to utilize social assistance benefits, the substantial underreporting of means-tested transfers in the CPS ASEC is likely to overstate the real extent of the blackwhite child poverty gap.

In applying the benefit imputations and comprehensive income definition, this paper has the added benefit of providing the most accurate assessment of racial differences in child poverty outcomes. The uncorrected CPS ASEC data suggests that the black child poverty rate is 116 percent higher than that of white children over a three-year average of 2012 to 2014 (38 percent poverty rate among black children to 17.6 percent for white children); after applying the benefit corrections, the ratio falls to 107 percent (29.6 percent poverty rate among black children to 14.3 percent for white children).

\section{Findings}

\section{DESCRIPTIVE FINDINGS}

I first present descriptive findings on the relationship between a child's race and states' TANF spending priorities. 
Figure 2: Bivariate associations between black share of a state's population vs. share of state's TANF budget allocated toward TANF spending priorities (avg., 2012 to 2014)
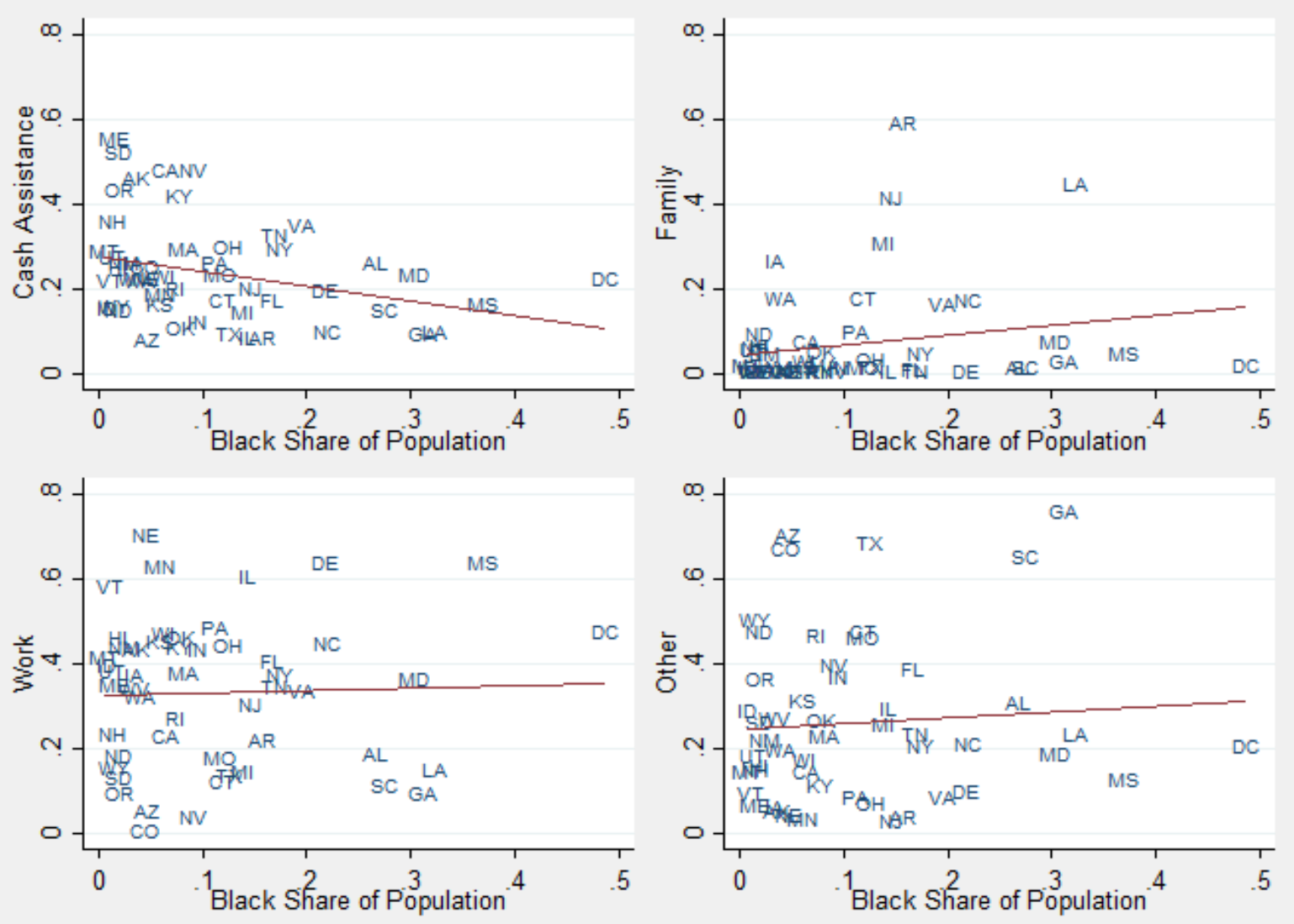

Note: See Table 1 for overview of spending categories. Correlations with black share of state population: Cash ( $\mathrm{r}=-.30)$, Family $(\mathrm{r}=.19)$, Work $(\mathrm{r}=.05)$, Other $(\mathrm{r}=.06)$.

As Figure 2 illustrates, a negative relationship ( $\mathrm{r}=-.30)$ exists between the share of black residents within a state and the state's relative prioritization of cash assistance, providing preliminary evidence of racial imbalances in TANF spending priorities. A positive correlation $(\mathrm{r}=.19)$ between race and the discouragement of lone motherhood exists, though the relationship does not appear to be linear. Iowa, for example, allocated more than 25 percent of its TANF budget toward the 'Family' strategy despite having a small (under 5 percent) share of black residents. Alabama and Washington D.C., both of which feature a comparatively large black population, spent very little toward this aim. No strong relationship appears to exist between a state's share of black residents and allocations toward 'the facilitation \& incentivization of employment' ( $\mathrm{r}=.05)$ or 'other services' $(\mathrm{r}=.06)$ priorities. 


\section{SOURCES OF VARIATION IN STATES'TANF SPENDING PRIORITIES}

To what extent do these relationships hold over time, and to what extent are they conditional on the economic and political variables identified previously? I now test this in the 'within-between' random effects model, the results of which are presented in Table 2.

Table 2: Random-Effects Model Predicting Allocations of States' TANF Budgets from 1997 to 2014: Standardized Coefficients (z-scores)

\begin{tabular}{|c|c|c|c|c|}
\hline & Cash & Family & Work & Other \\
\hline \multicolumn{5}{|l|}{ Between-State Effects } \\
\hline $\begin{array}{l}\text { Black Share of } \\
\text { Population }\end{array}$ & $\begin{array}{c}-0.091 * * * \\
(-3.67)\end{array}$ & $\begin{array}{l}0.066^{*} \\
(2.03)\end{array}$ & $\begin{array}{l}0.048 \\
(1.56)\end{array}$ & $\begin{array}{l}-0.034 \\
(-0.92)\end{array}$ \\
\hline $\begin{array}{l}\text { Asian Share of } \\
\text { Population }\end{array}$ & $\begin{array}{l}0.033 \\
(1.81)\end{array}$ & $\begin{array}{l}-0.010 \\
(-1.04)\end{array}$ & $\begin{array}{c}0.0048 \\
(0.25)\end{array}$ & $\begin{array}{l}-0.019 \\
(-0.63)\end{array}$ \\
\hline $\begin{array}{l}\text { Hispanic Share of } \\
\text { Population }\end{array}$ & $\begin{array}{l}-0.017 \\
(-0.80)\end{array}$ & $\begin{array}{c}0.0088 \\
(0.68)\end{array}$ & $\begin{array}{l}-0.011 \\
(-0.60)\end{array}$ & $\begin{array}{l}0.017 \\
(0.54)\end{array}$ \\
\hline $\begin{array}{l}\text { TANF Budget per } \\
\text { Child }\end{array}$ & $\begin{array}{l}0.022^{*} \\
(2.13)\end{array}$ & $\begin{array}{c}-0.0074 \\
(-0.90)\end{array}$ & $\begin{array}{l}-0.0065 \\
(-0.65)\end{array}$ & $\begin{array}{c}-0.0064 \\
(-0.38)\end{array}$ \\
\hline GDP Per Capita & $\begin{array}{c}-0.00099 \\
(-0.07)\end{array}$ & $\begin{array}{l}-0.0061 \\
(-0.72)\end{array}$ & $\begin{array}{l}-0.020 \\
(-1.01)\end{array}$ & $\begin{array}{l}0.024 \\
(0.84)\end{array}$ \\
\hline Union Density & $\begin{array}{c}0.0040 \\
(0.22)\end{array}$ & $\begin{array}{l}0.016 \\
(0.92)\end{array}$ & $\begin{array}{l}0.029 \\
(1.24)\end{array}$ & $\begin{array}{l}-0.053 \\
(-1.57)\end{array}$ \\
\hline Unemployment Rate & $\begin{array}{l}-0.029 \\
(-0.65)\end{array}$ & $\begin{array}{l}-0.026 \\
(-1.02)\end{array}$ & $\begin{array}{l}-0.074 \\
(-1.46)\end{array}$ & $\begin{array}{l}0.15^{*} \\
(2.29)\end{array}$ \\
\hline $\begin{array}{l}\text { Employment Rate of } \\
\text { Single Mothers }\end{array}$ & $\begin{array}{l}-0.0027 \\
(-0.10)\end{array}$ & $\begin{array}{l}-0.026 \\
(-0.95)\end{array}$ & $\begin{array}{l}-0.028 \\
(-0.71)\end{array}$ & $\begin{array}{l}0.069 \\
(1.76)\end{array}$ \\
\hline $\begin{array}{l}\text { Share of Children in } \\
\text { Single Parent HH }\end{array}$ & $\begin{array}{l}0.073^{*} \\
(2.35)\end{array}$ & $\begin{array}{l}-0.061 \\
(-1.59)\end{array}$ & $\begin{array}{c}0.0034 \\
(0.08)\end{array}$ & $\begin{array}{r}0.0077 \\
(0.14)\end{array}$ \\
\hline Democrat Governor & $\begin{array}{l}0.017 \\
(0.48)\end{array}$ & $\begin{array}{l}-0.015 \\
(-0.56)\end{array}$ & $\begin{array}{l}0.094 \\
(1.61)\end{array}$ & $\begin{array}{l}-0.082 \\
(-1.58)\end{array}$ \\
\hline $\begin{array}{l}\text { Democrat Share of } \\
\text { State Legislature }\end{array}$ & $\begin{array}{c}0.00018 \\
(0.01)\end{array}$ & $\begin{array}{l}0.016 \\
(1.24)\end{array}$ & $\begin{array}{l}-0.025 \\
(-1.13)\end{array}$ & $\begin{array}{c}0.0029 \\
(0.09)\end{array}$ \\
\hline
\end{tabular}


Within-State Effects

0.079

$-0.054$

$-0.044$

0.012

Population

(1.94)

$(-0.81)$

$(-0.83)$

$(0.21)$

Asian Share of

$-0.0085$

0.021

$-0.037$

0.044

Population

$(-0.28)$

(0.91)

(1.50)

Hispanic Share of

$-0.18 * * *$

0.023

$(-1.26)$

$(-3.47)$

(0.67)

0.034

$0.11 *$

Population

$-0.085^{*}$

0.0098

(0.57)

TANF Budget per

$(-2.25)$

(0.72)

$0.054 * *$

0.010

Child

GDP Per Capita

$-0.011$

0.0023

0.070

$-0.020$

$(-0.29)$

(0.14)

(1.56)

$(-0.48)$

Union Density

0.0099

$-0.016$

$-0.021$

0.019

(0.36)

$(-0.81)$

(0.75)

Unemployment Rate

0.012

0.0011

$(-0.65)$

0.0064

(1.55)

(0.28)

(0.85)

Employment Rate of

$-0.024 *$

0.0021

$-0.013$

$(0.85)$

Single Mothers

$(-2.24)$

(0.41)

0.017

0.0079

(1.46)

Share of Children in

$-0.0083$

0.013

0.028

$-0.010$

Single Parent HH

$(-0.50)$

(1.03)

$(-0.64)$

Democrat Governor

$-0.010$

0.014

(1.62)

$-0.010$

$(-0.79)$

(0.98)

0.0032

$(-0.82)$

Democrat Share of

$-0.013$

$-0.0093$

(0.21)

$-0.017$

State Legislature

$(-0.88)$

$(-0.38)$

$0.055 * *$

$(-0.92)$

Year Fixed Effects

X

X

X

X

\begin{tabular}{lllll}
\hline Observations & 918 & 918 & 918 & 918 \\
$\mathrm{R}-\mathrm{Sq}$ (within) & .533 & .179 & .208 & .236 \\
$\mathrm{R}-\mathrm{Sq}$ (between) & .384 & .224 & .208 & .326 \\
\hline Note: $\mathrm{z}$ scores in parentheses. X-standardized coefficients are presented for non-binary variables. Constant no
\end{tabular}
displayed. Cash: Provision of Cash Assistance; Work: Facilitation \& Incentivization of Employment; Family: Discouragement of Lone Motherhood; Other: Other Services (see Table 1 for full details).

${ }^{*} p<0.05,{ }^{* *} p<0.01,{ }^{* * *} p<0.001$ 
Model 1 investigates the determinants of the share of a state's TANF allocations toward the provision of cash assistance ('cash'), while subsequent models evaluate determinants of the discouragement of single motherhood ('family'), the facilitation and incentivization of employment ('work'), and other services ('other') respectively. Standardized coefficients are presented for continuous variables, meaning that the slopes should be interpreted as the estimated effect of a one standard deviation increase in the variable listed.

The first model suggests that, across states, a one standard deviation (11.3 percentage point) difference in the percentage of black residents living in a state is associated with an average 9.1 percentage point difference in a state's allocations toward cash assistance, net of the other economic and political controls. This corroborates the study's first hypothesis and suggests that the presence of black families is, indeed, associated with lower prioritization the provision of cash assistance. An increase in the relative size of the black population within a state, however, has no significant effect on states' prioritization of cash assistance. Notably, trade union coverage, the share of Democratic legislators, and the presence of a Democratic governor have no significant effect on the prioritization of cash assistance, suggesting that race is more relevant than class struggle in explaining states' prioritization of cash assistance.

Estimating simplified variations of this model corroborates this finding. In a sensitivity check, for example, I reduce the model to only the structural predictors (GDP per capita and employment rates), plus union density and share of black residents, to estimate a state's allocation of TANF cash assistance. Including only union density and the structural variables, I find that a one standard deviation difference in union density across states is associated with a 4.6 percentage point increase in prioritization of cash assistance. This would be consistent with power resources theory. Adding in the black share of population in the estimate, however, renders the union variable insignificant and decreases the magnitude of its slope, while the between-state measure of black population is negative and significant, as in Table 2. 
These findings suggest that racial composition, rather than class struggle, is central to the politics that shape states' TANF spending priorities.

We also see from Table 2 that states with higher per-child TANF budget levels give greater prioritization to cash assistance. This is not a surprise: the size of states' TANF block grants is set according to the size of their AFDC caseloads in the mid-1990s (Falk 2016). Thus, this positive correlation suggests that states that spent more on cash assistance in the years prior to welfare reform still give greater priority to cash assistance under TANF. Though TANF budget sizes vary little over time, the finding from the within-state effect of TANF budget size suggests that when states do increase their budget levels (due a rise in state MOE spending), they tend to allocate the extra funds toward the facilitation of employment ('work') and reduce the relative share allocated toward cash assistance.

The second model of Table 2 estimates states' prioritization of the discouragement of lone motherhood. Again, the findings suggest that race plays a key role: a one standard deviation difference in the share of black residents is associated with an average 6.6 percentage point increase in the share of a state's TANF budget allocated toward policies and programs to discourage single parenthood. ${ }^{7}$ These findings support the study's hypothesis that the racial composition of a state is associated with its prioritization of the "discouragement of lone motherhood.' The third and fourth models - which examine the 'work' and 'other' prioritizations, respectively - find no significant effects related to the share of black residents within or across states.

As the next section will estimate the consequences of racial inequity in TANF spending priorities on child poverty outcomes over the three latest years of data (2012 to 2014), it is

\footnotetext{
${ }^{7}$ In a sensitivity check that includes a dummy variable marking the 11 former Confederate states, the relationship is only significant at the 10 percent level and the size of the effect falls to .056. This suggests that relationship between race and efforts to discourage lone motherhood is weaker outside of the American south.
} 
useful to narrow in on the marginal effects of race on states' TANF spending priorities during those three years. Figure 3 displays the average marginal effects of a state's share of black residents on TANF allocations toward (1) cash assistance and (2) the discouragement of single motherhood by year. To obtain these, I estimate the same models as before, but with an interaction between the year dummies and the between-state component of states' black populations. Unstandardized coefficients are now presented for the TANF spending priorities to achieve a more straightforward interpretation over time.

Figure 3: Average Marginal Effects of Black Share of States' Populations on TANF Spending Allocations by Year

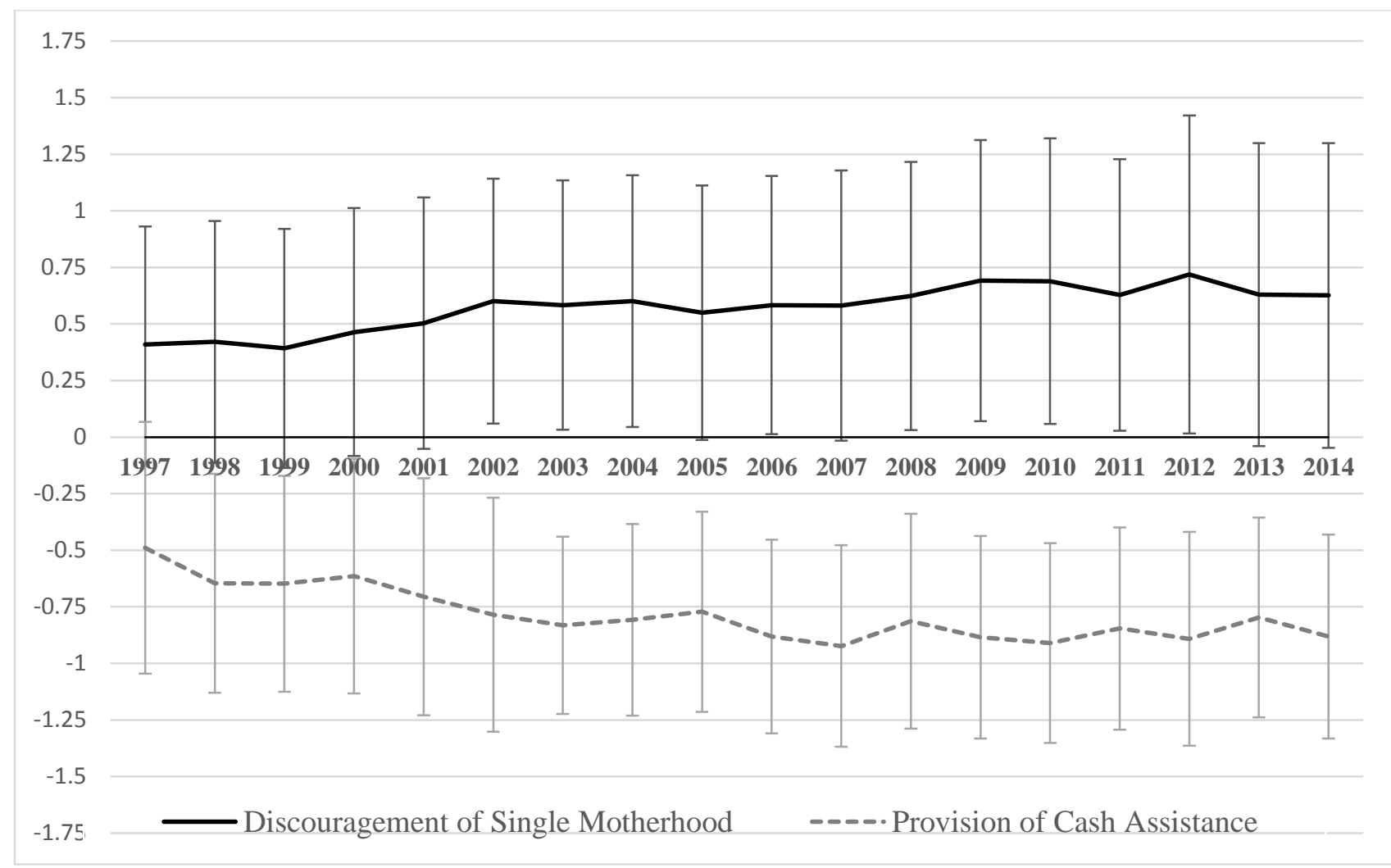

Note: Results from random effects model presented in Table 2 with interaction between year and black share of states' populations.

Over the three latest years of analysis (2012 to 2014), the estimated marginal effect of a state's share of black residents on the relative prioritization of cash assistance averaged at 0.857. This value is interpreted as the estimated racial bias against black residents in the share 
of TANF budgets allocated toward cash assistance during these years. Given that the average state had a black population of 11.4 percent, we can estimate that a 'neutralization' of the racial inequity would increase the average state's prioritization of cash assistance by 9.8 percentage points (the product of 0.857 and 11.4 percent). Put differently, the average state would have allocated more than 33.5 percent of its TANF budget toward 'cash' rather than the observed 23.7 percent over the years 2012 to 2014 . This difference is equivalent to a more than $\$ 3.3$ billion annual increase in cash assistance during these years.

\section{EFFECT OF TANF SPENDING PRIORITIES ON CHILD POVERTY}

I now turn toward predicting the effects of these racial inequities in TANF spending priorities on racial differences in child poverty outcomes. Recall from the Methods section that I test whether states' TANF spending priorities reduce the relative likelihood that a black child lives in poverty and, if so, whether this occurs through a composition or moderation effect. Table 3 presents the results of the multi-level linear probability models over the years 2012 to 2014. The first two columns present the random intercept models with and without the TANF spending priorities included. 
Table 3: Multi-Level Linear Probability Model Predicting Likelihood of Poverty Among Children, 2012 - 2014

\begin{tabular}{|c|c|c|c|c|c|c|c|}
\hline & $\begin{array}{c}\text { Random } \\
\text { Intercept: No } \\
\text { TANF } \\
\end{array}$ & $\begin{array}{c}\text { Random } \\
\text { Intercept: } \\
\text { With TANF }\end{array}$ & $\begin{array}{c}\text { Random } \\
\text { Slope: TANF } \\
\text { Cash }\end{array}$ & $\begin{array}{c}\text { Random } \\
\text { Slope: TANF } \\
\text { Family }\end{array}$ & $\begin{array}{c}\text { Random } \\
\text { Slope: TANF } \\
\text { Work }\end{array}$ & $\begin{array}{c}\text { Random } \\
\text { Slope: TANF } \\
\text { Other }\end{array}$ & $\begin{array}{c}\text { Random } \\
\text { Slope: All } \\
\text { Interactions } \\
\end{array}$ \\
\hline $\begin{array}{l}\text { TANF Budget Per } \\
\text { Child }\end{array}$ & & $\begin{array}{l}0.0090 \\
(1.06)\end{array}$ & $\begin{array}{l}0.0093 \\
(1.32)\end{array}$ & $\begin{array}{l}0.0094 \\
(1.33)\end{array}$ & $\begin{array}{l}0.0094 \\
(1.33)\end{array}$ & $\begin{array}{l}0.0091 \\
(1.31)\end{array}$ & $\begin{array}{l}0.0093 \\
(1.32)\end{array}$ \\
\hline TANF \% Cash & & $\begin{array}{l}0.013 \\
(0.33)\end{array}$ & $\begin{array}{l}0.022 \\
(0.61)\end{array}$ & $\begin{array}{l}0.020 \\
(0.55)\end{array}$ & $\begin{array}{l}0.020 \\
(0.55)\end{array}$ & $\begin{array}{l}-0.0035 \\
(-0.10)\end{array}$ & $\begin{array}{l}0.022 \\
(0.60)\end{array}$ \\
\hline TANF \%Work & & $\begin{array}{l}0.024 \\
(1.19)\end{array}$ & $\begin{array}{l}0.016 \\
(0.74)\end{array}$ & $\begin{array}{l}0.016 \\
(0.75)\end{array}$ & $\begin{array}{l}0.016 \\
(0.75)\end{array}$ & & $\begin{array}{l}0.016 \\
(0.76)\end{array}$ \\
\hline TANF \% Family & & $\begin{array}{l}0.037 \\
(1.09)\end{array}$ & $\begin{array}{l}0.00034 \\
(0.01)\end{array}$ & $\begin{array}{l}-0.0020 \\
(-0.08)\end{array}$ & $\begin{array}{l}0.00051 \\
(0.02)\end{array}$ & $\begin{array}{l}-0.023 \\
(-0.91)\end{array}$ & $\begin{array}{l}-0.0013 \\
(-0.05)\end{array}$ \\
\hline TANF \%Other & & & & & & $\begin{array}{l}-0.028 \\
(-1.32)\end{array}$ & \\
\hline $\begin{array}{l}\text { TANF \% Cash \# } \\
\text { 'Black' }\end{array}$ & & & $\begin{array}{l}-0.24^{* *} \\
(-2.98)\end{array}$ & & & & $\begin{array}{l}-0.22^{* *} \\
(-2.66)\end{array}$ \\
\hline $\begin{array}{l}\text { TANF \% Family \# } \\
\text { 'Black' }\end{array}$ & & & & $\begin{array}{l}0.20 \\
(1.37)\end{array}$ & & & $\begin{array}{l}0.11 \\
(0.79)\end{array}$ \\
\hline $\begin{array}{l}\text { TANF \% Work \# } \\
\text { 'Black' }\end{array}$ & & & & & $\begin{array}{l}-0.014 \\
(-0.21)\end{array}$ & & $\begin{array}{l}-0.033 \\
(-0.54)\end{array}$ \\
\hline $\begin{array}{l}\text { TANF \% Other \# } \\
\text { 'Black' }\end{array}$ & & & & & & $\begin{array}{l}0.089 \\
(1.67)\end{array}$ & \\
\hline
\end{tabular}




\begin{tabular}{|c|c|c|c|c|c|c|c|}
\hline Black & $\begin{array}{l}0.038^{* * * *} \\
(5.25)\end{array}$ & $\begin{array}{l}0.038^{* * *} \\
(5.24)\end{array}$ & $\begin{array}{l}0.11^{* * *} \\
(4.46)\end{array}$ & $\begin{array}{l}0.027^{* *} \\
(2.87)\end{array}$ & $\begin{array}{l}0.041 \\
(1.82)\end{array}$ & $\begin{array}{l}0.018 \\
(1.26)\end{array}$ & $\begin{array}{l}0.11^{* *} \\
(2.92)\end{array}$ \\
\hline Hispanic & $\begin{array}{l}0.043^{* * *} \\
(8.79)\end{array}$ & $\begin{array}{l}0.043^{* * *} \\
(8.82)\end{array}$ & $\begin{array}{l}0.042^{* * *} \\
(8.37)\end{array}$ & $\begin{array}{l}0.042^{* * *} \\
(8.37)\end{array}$ & $\begin{array}{l}0.042^{* * *} \\
(8.37)\end{array}$ & $\begin{array}{l}0.042^{* * * *} \\
(8.39)\end{array}$ & $\begin{array}{l}0.042^{* * *} \\
(8.36)\end{array}$ \\
\hline Asian & $\begin{array}{l}0.0089 \\
(1.11)\end{array}$ & $\begin{array}{l}0.0089 \\
(1.11)\end{array}$ & $\begin{array}{l}0.0062 \\
(0.79)\end{array}$ & $\begin{array}{l}0.0062 \\
(0.79)\end{array}$ & $\begin{array}{l}0.0062 \\
(0.79)\end{array}$ & $\begin{array}{l}0.0062 \\
(0.79)\end{array}$ & $\begin{array}{l}0.0062 \\
(0.79)\end{array}$ \\
\hline $\begin{array}{l}\text { Other Non-White } \\
\text { Race }\end{array}$ & $\begin{array}{l}0.020^{*} \\
(2.27)\end{array}$ & $\begin{array}{l}0.020^{*} \\
(2.27)\end{array}$ & $\begin{array}{l}0.020^{*} \\
(2.25)\end{array}$ & $\begin{array}{l}0.020^{*} \\
(2.25)\end{array}$ & $\begin{array}{l}0.020^{*} \\
(2.25)\end{array}$ & $\begin{array}{l}0.020^{*} \\
(2.25)\end{array}$ & $\begin{array}{l}0.020^{*} \\
(2.25)\end{array}$ \\
\hline Non-Citizen Head & $\begin{array}{l}0.13^{* * *} \\
(16.13)\end{array}$ & $\begin{array}{l}0.13^{* * *} \\
(16.12)\end{array}$ & $\begin{array}{l}0.13^{* * *} \\
(15.96)\end{array}$ & $\begin{array}{l}0.13^{* * *} \\
(15.96)\end{array}$ & $\begin{array}{l}0.13^{* * *} \\
(15.96)\end{array}$ & $\begin{array}{l}0.13^{* * *} \\
(15.96)\end{array}$ & $\begin{array}{l}0.13^{* * *} \\
(15.96)\end{array}$ \\
\hline $\begin{array}{l}\text { Head Age Under } \\
25\end{array}$ & $\begin{array}{l}0.083^{* * *} \\
(11.99)\end{array}$ & $\begin{array}{l}0.083^{* * *} \\
(12.00)\end{array}$ & $\begin{array}{l}0.083^{* * *} \\
(11.99)\end{array}$ & $\begin{array}{l}0.083^{* * *} \\
(11.99)\end{array}$ & $\begin{array}{l}0.083^{* * *} \\
(11.99)\end{array}$ & $\begin{array}{l}0.083^{* * *} \\
(11.99)\end{array}$ & $\begin{array}{l}0.083^{* * *} \\
(11.99)\end{array}$ \\
\hline Head Age 25 - 34 & $\begin{array}{l}0.011^{* *} \\
(2.87)\end{array}$ & $\begin{array}{l}0.011^{* *} \\
(2.87)\end{array}$ & $\begin{array}{l}0.011^{* *} \\
(2.91)\end{array}$ & $\begin{array}{l}0.011^{* *} \\
(2.91)\end{array}$ & $\begin{array}{l}0.011^{* *} \\
(2.91)\end{array}$ & $\begin{array}{l}0.011^{* *} \\
(2.91)\end{array}$ & $\begin{array}{l}0.011^{* *} \\
(2.91)\end{array}$ \\
\hline Head Age 54 - 65 & $\begin{array}{l}0.00043 \\
(0.09)\end{array}$ & $\begin{array}{l}0.00043 \\
(0.09)\end{array}$ & $\begin{array}{l}0.00019 \\
(0.04)\end{array}$ & $\begin{array}{l}0.00020 \\
(0.04)\end{array}$ & $\begin{array}{l}0.00021 \\
(0.04)\end{array}$ & $\begin{array}{l}0.00021 \\
(0.04)\end{array}$ & $\begin{array}{l}0.00019 \\
(0.04)\end{array}$ \\
\hline Head Age 66+ & $\begin{array}{l}-0.0074 \\
(-0.58)\end{array}$ & $\begin{array}{l}-0.0074 \\
(-0.57)\end{array}$ & $\begin{array}{l}-0.0075 \\
(-0.58)\end{array}$ & $\begin{array}{l}-0.0075 \\
(-0.58)\end{array}$ & $\begin{array}{l}-0.0075 \\
(-0.58)\end{array}$ & $\begin{array}{l}-0.0075 \\
(-0.58)\end{array}$ & $\begin{array}{l}-0.0075 \\
(-0.58)\end{array}$ \\
\hline $\begin{array}{l}\text { Head Less Than } \\
\text { High School }\end{array}$ & $\begin{array}{l}0.070^{* * *} \\
(14.20)\end{array}$ & $\begin{array}{l}0.070^{* * *} \\
(14.20)\end{array}$ & $\begin{array}{l}0.070^{* * *} \\
(14.21)\end{array}$ & $\begin{array}{l}0.070^{* * *} \\
(14.21)\end{array}$ & $\begin{array}{l}0.070^{* * *} \\
(14.21)\end{array}$ & $\begin{array}{l}0.070^{* * * *} \\
(14.20)\end{array}$ & $\begin{array}{l}0.070^{* * *} \\
(14.21)\end{array}$ \\
\hline $\begin{array}{l}\text { Head College or } \\
\text { More }\end{array}$ & $\begin{array}{l}-0.024^{* * *} \\
(-9.61)\end{array}$ & $\begin{array}{l}-0.024^{* * *} \\
(-9.62)\end{array}$ & $\begin{array}{l}-0.025^{* * *} \\
(-10.02)\end{array}$ & $\begin{array}{l}-0.025^{* * *} \\
(-10.01)\end{array}$ & $\begin{array}{l}-0.025^{* * *} \\
(-10.01)\end{array}$ & $\begin{array}{l}-0.025^{* * *} \\
(-10.02)\end{array}$ & $\begin{array}{l}-0.025^{* * * *} \\
(-10.01)\end{array}$ \\
\hline
\end{tabular}




\begin{tabular}{|c|c|c|c|c|c|c|c|}
\hline $\begin{array}{l}\text { Single Mother } \\
\text { Household }\end{array}$ & $\begin{array}{l}0.094^{* * *} \\
(12.69)\end{array}$ & $\begin{array}{l}0.094^{* * *} \\
(12.69)\end{array}$ & $\begin{array}{l}0.094^{* * *} \\
(12.61)\end{array}$ & $\begin{array}{l}0.094^{* * *} \\
(12.62)\end{array}$ & $\begin{array}{l}0.094^{* * *} \\
(12.62)\end{array}$ & $\begin{array}{l}0.094^{* * *} \\
(12.61)\end{array}$ & $\begin{array}{l}0.094^{* * *} \\
(12.61)\end{array}$ \\
\hline $\begin{array}{l}\text { Single Father } \\
\text { Household }\end{array}$ & $\begin{array}{l}0.0076 \\
(1.18)\end{array}$ & $\begin{array}{l}0.0076 \\
(1.18)\end{array}$ & $\begin{array}{l}0.0076 \\
(1.17)\end{array}$ & $\begin{array}{l}0.0076 \\
(1.17)\end{array}$ & $\begin{array}{l}0.0076 \\
(1.17)\end{array}$ & $\begin{array}{l}0.0076 \\
(1.17)\end{array}$ & $\begin{array}{l}0.0076 \\
(1.17)\end{array}$ \\
\hline Jobless Household & $\begin{array}{l}0.41^{* * * *} \\
(27.03)\end{array}$ & $\begin{array}{l}0.41^{* * *} \\
(27.03)\end{array}$ & $\begin{array}{l}0.41^{* * *} \\
(27.35)\end{array}$ & $\begin{array}{l}0.41^{* * * *} \\
(27.34)\end{array}$ & $\begin{array}{l}0.41^{* * * *} \\
(27.34)\end{array}$ & $\begin{array}{l}0.41^{* * *} \\
(27.34)\end{array}$ & $\begin{array}{l}0.41^{* * *} \\
(27.35)\end{array}$ \\
\hline $\begin{array}{l}\text { Dual-Earner } \\
\text { Household }\end{array}$ & $\begin{array}{l}-0.11^{* * *} \\
(-15.97)\end{array}$ & $\begin{array}{l}-0.11^{* * *} \\
(-15.97)\end{array}$ & $\begin{array}{l}-0.11^{* * *} \\
(-15.91)\end{array}$ & $\begin{array}{l}-0.11^{* * *} \\
(-15.91)\end{array}$ & $\begin{array}{l}-0.11^{* * *} \\
(-15.91)\end{array}$ & $\begin{array}{l}-0.11^{\text {**** }} \\
(-15.91)\end{array}$ & $\begin{array}{l}-0.11^{* * *} \\
(-15.91)\end{array}$ \\
\hline $\begin{array}{l}\text { \# of Children in } \\
\text { Household }\end{array}$ & $\begin{array}{l}0.020^{* * * *} \\
(10.38)\end{array}$ & $\begin{array}{l}0.020^{* * * *} \\
(10.38)\end{array}$ & $\begin{array}{l}0.020^{* * *} \\
(10.24)\end{array}$ & $\begin{array}{l}0.020^{* * *} \\
(10.24)\end{array}$ & $\begin{array}{l}0.020^{* * * *} \\
(10.24)\end{array}$ & $\begin{array}{l}0.020^{* * *} \\
(10.24)\end{array}$ & $\begin{array}{l}0.020^{* * * *} \\
(10.24)\end{array}$ \\
\hline $\begin{array}{l}\text { \# of Age } 66+\text { in } \\
\text { Household }\end{array}$ & $\begin{array}{l}-0.031^{* * *} \\
(-7.45)\end{array}$ & $\begin{array}{l}-0.031^{* * *} \\
(-7.45)\end{array}$ & $\begin{array}{l}-0.030^{\text {**** }} \\
(-7.34)\end{array}$ & $\begin{array}{l}-0.030^{* * *} \\
(-7.34)\end{array}$ & $\begin{array}{l}-0.030^{* * * *} \\
(-7.34)\end{array}$ & $\begin{array}{l}-0.030^{* * *} \\
(-7.34)\end{array}$ & $\begin{array}{l}-0.030^{* * *} \\
(-7.34)\end{array}$ \\
\hline $\begin{array}{l}\text { Unemployment } \\
\text { Rate }\end{array}$ & $\begin{array}{l}0.013^{* * *} \\
(5.56)\end{array}$ & $\begin{array}{l}0.013^{* * *} \\
(5.42)\end{array}$ & $\begin{array}{l}0.012^{* * *} \\
(4.74)\end{array}$ & $\begin{array}{l}0.012^{* * *} \\
(4.77)\end{array}$ & $\begin{array}{l}0.012^{* * *} \\
(4.77)\end{array}$ & $\begin{array}{l}0.012^{* * *} \\
(4.81)\end{array}$ & $\begin{array}{l}0.012^{* * *} \\
(4.75)\end{array}$ \\
\hline Union Density & $\begin{array}{l}-0.020^{* * *} \\
(-3.82)\end{array}$ & $\begin{array}{l}-0.020^{* * *} \\
(-3.89)\end{array}$ & $\begin{array}{l}-0.019^{* * *} \\
(-3.94)\end{array}$ & $\begin{array}{l}-0.019^{* * *} \\
(-3.95)\end{array}$ & $\begin{array}{l}-0.019^{* * *} \\
(-3.96)\end{array}$ & $\begin{array}{l}-0.019^{* * *} \\
(-4.10)\end{array}$ & $\begin{array}{l}-0.019^{* * *} \\
(-3.93)\end{array}$ \\
\hline GDP Per Capita & $\begin{array}{l}-0.013^{* * *} \\
(-4.13)\end{array}$ & $\begin{array}{l}-0.012^{* * *} \\
(-3.95)\end{array}$ & $\begin{array}{l}-0.008^{* * *} \\
(-3.33)\end{array}$ & $\begin{array}{l}-0.008^{* * *} \\
(-3.33)\end{array}$ & $\begin{array}{l}-0.008^{* * * *} \\
(-3.33)\end{array}$ & $\begin{array}{l}-0.008^{* * *} \\
(-3.29)\end{array}$ & $\begin{array}{l}-0.008^{* * *} \\
(-3.34)\end{array}$ \\
\hline Minimum Wage & $\begin{array}{l}-0.011^{* * *} \\
(-4.07)\end{array}$ & $\begin{array}{l}-0.011^{* * *} \\
(-3.79)\end{array}$ & $\begin{array}{l}-0.012^{* * *} \\
(-4.21)\end{array}$ & $\begin{array}{l}-0.012^{* * *} \\
(-4.22)\end{array}$ & $\begin{array}{l}-0.012^{* * *} \\
(-4.23)\end{array}$ & $\begin{array}{l}-0.011^{* * *} \\
(-4.19)\end{array}$ & $\begin{array}{l}-0.012^{* * *} \\
(-4.21)\end{array}$ \\
\hline State SSI Bonus & -0.000 & 0.000 & 0.000 & 0.000 & 0.000 & -0.000 & 0.000 \\
\hline
\end{tabular}




$\begin{array}{llllllll} & (-0.36) & (0.29) & (0.07) & (0.07) & (0.08) & (-0.72) & (0.07) \\ \text { State EITC } & & & & & -0.023 & -0.023 & -0.0056 \\ \text { Supplement } & -0.0070 & -0.042 & -0.023 & -0.023 & -0.023 \\ & (-0.24) & (-1.04) & (-0.62) & (-0.62) & (-0.62) & (-0.19)\end{array}$

All models include year fixed effects. $\mathrm{N}=150,279 . z$ scores in parentheses; $\mathrm{X}$-standardized coefficients are presented for non-TANF state controls (unemployment rate, union density, minimum wage, and GDP per capita). Constant not displayed. ${ }^{*} p<0.05,{ }^{* * *} p<0.01,{ }^{* * *} p<0.001$ 
Evidence supporting the composition effect should show, at a minimum, that the probability of poverty for the 'Black' racial category decrease from the first model to the second. This would suggest that accounting for TANF priorities reduces the poverty risk attached to a black child's race. Instead, it remains constant at 0.038 and each of the TANF spending priorities is insignificant. From this, we can deduce that the four spending priorities do not have an observable effect on child poverty net of the other state-, household-, and individual-level controls.

It may be, however, that differences in spending priorities across states affect the relative probability of poverty attached to a black child's race. If this moderation effect exists, we should expect to find a significant cross-level interaction between the respective TANF spending priority and our 'Black' variable. This would indicate that, say, the probability of poverty associated with being black are higher or lower when states give greater priority to the TANF spending priority. The final four columns test this effect.

The third column provides the results of a random-slope model with a cross-level interaction between a black child's race and states' prioritization of TANF cash assistance. The three spending priorities remain insignificant; the cross-level interaction, however, reveals that higher allocations of TANF cash assistance reduce the probability of poverty for a black child. Specifically, a 10 percent increase in the share of the average state's budget allocated toward 'cash' leads to an estimated 2.4 percentage point reduction in the likelihood that a black child, relative to a white child, lives in poverty. The fourth column shows that the cross-level interaction for allocations toward the 'discouragement of lone motherhood' priority is positively signed, but insignificant, suggesting that investment toward this end has no observable effect on poverty outcomes. ${ }^{8}$ The cross-level interaction for 'work' is

\footnotetext{
${ }^{8}$ In analyses available upon request, I also test whether spending toward 'family' affects the likelihood of a child living in a single-mother family. In multi-level models, the 'family'
} 
negatively signed but also insignificant. ${ }^{9}$

The final model includes each of the cross-level interactions into the same model. Again, the provision of cash assistance appears to reduce the likelihood that a black child lives in poverty. Even after controlling for the interaction effects of the other spending priorities, a 10 percentage point increase in the share of a state's budget allocation toward 'cash' is associated with a 2.2 percentage point reduction in the relative likelihood that a black child lives in poverty. Before, we observed that 'neutralizing' the racial bias in states' allocation of cash assistance would result in the average state spending 9.8 percentage points more of its TANF budget on cash assistance. Using the finding from the cross-level interaction in Table 3, we can thus estimate that a 9.8 percentage point increase in the prioritization of 'cash' would reduce a black child's likelihood of poverty by 2.16 percentage points (the product of .098 and -.22). If this were to occur, the poverty rate among black children would fall from 29.5 to 27.3 percent, and the black-white child poverty gap would fall from 107 to 90.1 percent, a 15 percent decline.

Such a shift would mark the first time since at least 1993 that black children were less than twice as likely as white children to live in poverty. Important to reiterate, this estimate assumes that the average state would allocate a mere 33.5 percent of its TANF budget (rather than the observed 23.7 percent) toward the provision of cash assistance, still less than half the

prioritization is positively signed but statistically insignificant, even when applied in a cross-level interaction with the 'black' variable. I also test two-way fixed effects models using longitudinal data (1993 to 2014), but again find no significant effect.

${ }^{9}$ One could be concerned that controlling for household joblessness and household composition absorbs much of the potential effect of the "Work" or "Family" spending priorities on child poverty outcomes. To address this possibility, I re-estimate all the models while dropping household-level controls and only including state-level controls and the child's race and nativity status. Results available upon request show that the Work and Family spending priorities remain statistically insignificant with no large difference in effect size. The effect of the "Cash" spending priority, however, increases in magnitude (a stronger anti-poverty effect) and remains statistically significant. Thus, the inclusion of the household controls appear to provide a more conservative and appropriate estimate of the effect of TANF spending priorities on the black-white child poverty gap. 
average state's allocation in 1997 (65 percent). As shown in the supplementary appendix, a multi-level logistic regression model applying the same cross-level interaction also finds that higher levels of cash assistance reduce the relative likelihood that a black child lives in poverty. As hypothesized, racial inequities in states' TANF spending priorities do, indeed, contribute to the black-white child poverty gap.

To what extent can differences in the size of states' TANF budgets, rather than relative allocations of the budgets, explain differences in child poverty rates? In short, not much. In the supplementary appendix (Table S2), I test whether a larger TANF budget, independent of allocations, affects the relative likelihood that a black child lives in poverty. A cross-level interaction between TANF budget per child and 'Black' is statistically insignificant. The interaction of allocations toward TANF cash assistance and 'Black' remains significant and negative even when controlling for the cross-level interaction with budget size. Finally, a triple interaction of TANF budget size, allocations toward cash assistance, and 'Black' provides suggestive evidence that when states with larger TANF budgets allocate a greater share of that budget toward cash assistance, the relative likelihood that a black child lives in poverty falls by an even greater amount (the negative slope is significant at the 10 percent level). These findings corroborate this study's claim that the allocations of states' TANF budgets, rather than the size of the budget, are more consequential in explaining the blackwhite child poverty gap.

To contrast the relative effects of bias in TANF spending on racial poverty differences, we can compare its effect with the change in the black-white poverty gap if the prevalence of children living in single-mother households were reduced to zero. In other words, we can ask: if all single mothers found a partner tomorrow, what would be the estimated effect on the black-white child poverty gap? We can then compare the effect to that of neutralizing racial bias in states' TANF spending priorities. In Table 3, we see that if a child lives in a single 
mother household, his or her likelihood of poverty increases by 9.4 percentage points. Using a standard decomposition technique (Brady, Finnigan and Hübgen 2017, Gornick and Jäntti 2012) that replaces the observed prevalence of children in single-mother households $(24.1$ percent) with the counterfactual prevalence (zero) while keeping all else constant, we can estimate that the overall child poverty rate by fall by from 16.7 to 14.4 percent, with disproportionate gains for black children. The black-white child poverty gap would fall by 10.4 percent (from 106 to 95 percent) — a notable amount, but less than the relative gains (15 percent) if racial bias in states' TANF spending priorities were to be neutralized.

In the supplementary appendix (Table S3), I provide further evidence that greater prioritization of TANF cash assistance reduces the relative likelihood that a black child lives in poverty independent of its effect on the likelihood that a single mother household lives in poverty. In other words, the effect of TANF cash does not reduce the black-white child poverty gap solely through a reduction in the poverty likelihood attached to single motherhood. In fact, a triple interaction of TANF cash, black, and single motherhood demonstrates that greater prioritization of cash assistance reduces the likelihood that a black child in a single-mother household lives in poverty (relative to a non-black child in a singlemother household). Even among single-mother households, then, racial bias in states' TANF priorities can be linked to racial differences in child poverty outcomes. These findings make clear that a focus on family structure is incomplete as an explanation for differences in child poverty rates between white and black children.

\section{ROBUSTNESS CHECKS}

To corroborate the finding that racial inequity in states' provision of cash assistance worsens the black-white child poverty gap, I include three sets of robustness checks in the supplementary appendix. These include (1) a static microsimulation estimate of poverty rates 
if racial inequities in states' TANF priorities were to be neutralized, (2) use of a fixed effects model rather than multi-level model to assess the moderating effects of TANF spending priorities on black child poverty, and (3) a re-estimation of the primary analyses but with a measure of poverty based on 50 percent of each state's respective median income (rather than the national median). The findings from each of the robustness checks corroborate the findings from the primary analysis.

\section{Discussion}

Why are black children in the United States likelier than white children to live in poverty? In contrast to the literature's dominant focus on family structure, this paper set out to investigate how state-level inequities in administration of the TANF program contribute to racial differences in child poverty. I demonstrate that racial bias in states' allocations of TANF resources explains a significant share of the black-white child poverty gap. In fact, reducing inequities in states' allocation of cash assistance would have a reduction effect on the black-white child poverty gap comparable to that of moving all children in single-mother households to two-parent households. These findings emphasize that inequity in welfare state institutions must be central to understanding racial inequities in child poverty outcomes.

To arrive at these findings, I introduced a typology to classify the distinct spending priorities toward which states allocate their TANF funds. Building on prior findings of racial discrimination in social policy, I then empirically assessed how the prevalence of black residents within a state is associated with differences in states' TANF spending priorities, as well as the consequences of this estimated inequity on racialized child poverty outcomes. Uniting these previously disconnected analyses with more accurate household income data and a more robust analytical approach leads to a novel understanding of how inequities in social policy across the 50 states contribute to racial divides. 
From 2012 to 2014, racial inequity in states' TANF spending priorities can be attributed to an estimated $\$ 3.3$ billion annual average decline in amount of cash assistance provided to low-income families. The estimates presented suggest that neutralizing this bias would reduce the black-white child poverty gap by up to 15 percent. The level of poverty among black children would fall from 29.5 to an estimated 27.3 percent - a difference of approximately 256,000 black children per year.

These findings offer several implications for American poverty and sociology research. Adding to comparative policy literature that has emphasized the political and institutional determinants of poverty, this paper demonstrates that state governments and inequities in state-administered social policies play an important role in generating racialized child poverty outcomes. The likelihood that a black child lives in poverty cannot merely be attributed to family structure nor characteristics of the child's family. Instead, cross-state inequities in the provision of social assistance and, specifically, administration of the TANF program, must be taken into account. The framework introduced to conceptualize the four distinct TANF spending priorities builds on a long tradition within comparative social policy research of classifying differences across welfare states and can be applied in future research to further analyze the consequences of cross-state differences in the types of social assistance offered to low-income families.

Consistent with prior evidence on the racialization of social policy, I find that the presence of black families within a state holds more explanatory weight than political or economic forces in explaining a state's TANF spending priorities. Americans' perceptions of black families - lazy, undeserving, and receiving 'more than they deserve' (Gilens 1999, Katz 1990, Krimmel and Rader 2017) - do appear to funnel their way into state-level policy decisions. Adding to prior research that has connected states' racial compositions to social assistance policies (Soss, Fording and Schram 2011), I find that race affects more than just 
'cash': states with greater shares of black residents, ceteris paribus, are likely to invest more in policies and programs to discourage lone motherhood. These findings pose a challenge to power resources theory and other class-based arguments of welfare state development. While left parties and union strength can explain cross-national differences in the size and generosity of welfare states, this paper shows that within the U.S., racial composition is central to the state-level politics of poverty and social assistance policies.

This paper's findings also carry several policy implications. In broad terms, the evidence suggests that policymakers might be wise to consider whether TANF, in its current form, adequately serves the interests of low-income families. In 1997 and 1998, the average state spent more than half of its budget on cash assistance, around 10 percent on tangentiallyrelated services, and next to nothing on efforts to discourage lone motherhood. By 2014, 10 states allocated less than 10 percent of their TANF budgets toward the provision of cash assistance. Installing more stringent accountability mechanisms on the types of programs toward which states can allocate TANF funds, or instituting minimum standards of cash assistance provision, are two of many possible steps toward smoothing the racial inequities present in the TANF program.

Finally, it must be noted that the limitations of this paper likely lead to an underestimation of the real extent of racial inequity in states' social welfare programs. First, I only measure the extent of racial inequity as it exists within the framework of TANF, but TANF itself (among many other features of the American welfare state) may in some part be a product of racially-oriented prejudices (Quadagno 1994, Schram, Soss and Fording 2003, Soss, Fording and Schram 2011). Secondly, this paper focuses exclusively on racial inequity in the TANF program. Future research may extend this analysis beyond TANF to consider how state-level variation in minimum wage levels, supplements to the EITC, and the accessibility of health insurance mitigate regional and racial disparities in poverty. The role of 
states as a source of inequality, and state governments as institutions that foster racial differences in poverty outcomes, deserves increasing focus as American poverty research moves forward. 


\section{References}

Ai, Chunrong and Edward C. Norton. 2003. "Interaction Terms in Logit and Probit Models." Economics Letters 80(1):123-29. doi: https://doi.org/10.1016/S0165-1765(03)00032$\underline{6}$.

Alesina, Alberto, Edward Glaeser and Bruce Sacerdote. 2001. "Why Doesn't the Us Have a European-Style Welfare System?". National Bureau of Economic Research Working Paper Series No. 8524. doi: 10.3386/w8524.

Allison, Paul David. 2009. Fixed Effects Regression Models. Los Angeles, Calif. ; London: SAGE.

Bambra, C. 2007. "Going Beyond the Three Worlds of Welfare Capitalism: Regime Theory and Public Health Research." Journal of Epidemiology and Community Health 61(12):1098-102. doi: 10.1136/jech.2007.064295.

Bartels, Brandon. 2009. "Beyond Fixed Versus Random Effects: A Framework for Improving Substantive and Statistical Analysis of Panel, Time-Series Cross-Sectional, and Multilevel Data." Paper presented at the Political Methodology Conference, Ann Arbor, MI (http://home.gwu.edu/ bartels/cluster.pdf).

Bell, Andrew and Kelvyn Jones. 2014. "Explaining Fixed Effects: Random Effects Modeling of Time-Series Cross-Sectional and Panel Data." Political Science Research and Methods 3(1):133-53. doi: 10.1017/psrm.2014.7.

Blank, Rebecca M., Sheldon Danziger and Robert Schoeni. 2006. Working and Poor : How Economic and Policy Changes Are Affecting Low-Wage Workers. New York: Russell Sage Foundation.

Brady, David. 2009. Rich Democracies, Poor People: How Politics Explain Poverty. Oxford: Oxford University Press.

Brady, David, R Baker and R Finnigan. 2013. "When Unionization Disappears: State-Level Unionization and Working Poverty in the United States." American Sociological Review 78(5):872-96. doi: 10.1177/0003122413501859.

Brady, David, R Finnigan and S Hübgen. 2017. "Rethinking the Risks of Poverty: A Framework for Analyzing Prevlances and Penalties." American Journal of Sociology 123 (3):740-86.

Brown, Hana E. 2013a. "Racialized Conflict and Policy Spillover Effects: The Role of Race in the Contemporary U.S. Welfare State." American Journal of Sociology 119(2):394443. doi: 10.1086/674005.

Brown, Hana E. 2013b. "Race, Legality, and the Social Policy Consequences of AntiImmigration Mobilization." American Sociological Review 78(2):290-314. doi: 10.1177/0003122413476712.

Brown, Hana E. and Rachel Kahn Best. 2017. "Logics of Redistribution: Determinants of Generosity in Three U.S. Social Welfare Programs." Sociological Perspectives 60(4):786-809. doi: 10.1177/0731121416656843.

Center on Budget \& Policy Priorities. 2015. "State Fact Sheets: How States Have Spent Federal and State Funds under the Tanf Block Grant." Center on Budget \& Policy Priorities.

Citro, Constance F. and Robert T. Michael. 1995. Measuring Poverty : A New Approach. Washington, D.C.: National Academy Press.

Corak, Miles. 2005. "Principles and Practicalities for Measuring Child Poverty in the Rich Countries." IZA Working Papers (DP No. 1579).

Esping-Andersen, Gøsta. 1990. The Three Worlds of Welfare Capitalism. Cambridge: Polity. 
Fagan, Patrick and Kirk Johnson. 2001. "Understanding Differences in Black and White Child Poverty Rates." The Heritage Foundation.

Falk, Gene. 2014. "Temporary Assistance for Needy Families (Tanf): Eligibility and Benefit Amounts in State Tanf Cash Assistance Programs ". Congressional Research Service.

Falk, Gene. 2016. "The Temporary Assistance for Needy Families (Tanf) Block Grant: Responses to Frequently Asked Questions." Congressional Research Service.

Fellowes, Matthew C. and Gretchen Rowe. 2004. "Politics and the New American Welfare States." American Journal of Political Science 48(2):362-73. doi: 10.2307/1519888.

Foster, James E. 1998. "Absolute Versus Relative Poverty." The American Economic Review 88(2):335-41.

Fox, Cybelle. 2004. "The Changing Color of Welfare? How Whites' Attitudes toward Latinos Influence Support for Welfare." American Journal of Sociology 110(3):580-625. doi: $10.1086 / 422587$.

Fox, Liana, Irwin Garfinkel, Neeraj Kaushal, Jane Waldfogel and Christopher Wimer. 2014. "Waging War on Poverty Historical Trends in Poverty Using the Supplemental Poverty Measure." Cambridge, Mass.: National Bureau of Economic Research,. Retrieved. (http://www.nber.org/papers/w19789).

Garfinkel, Irwin and Sara McLanahan. 1986. Single Mothers and Their Children : A New American Dilemma. Washington, D.C.: Urban Institute Press.

Germanis, Peter. 2015. "Tanf Is Broken! It's Time to Reform "Welfare Reform”."

Gilens, Martin. 1999. Why Americans Hate Welfare : Race, Media, and the Politics of Antipoverty Policy. Chicago ; London: University of Chicago Press.

Goedemé, Tim and S. Rottiers. 2010. "Poverty in the Enlarged European Union. A Discussion About Definitions and Reference Groups." CSB Working Paper Series.

Gornick, Janet and Markus Jäntti. 2016. "Poverty." in The Poverty \& Inequality Report, edited by D. B. Grusky, M. J. Mattingly and C. E. Varner. Stanford: The Stanford Center on Poverty \& Inequality.

Gornick, Janet C. and Markus Jäntti. 2012. "Child Poverty in Cross-National Perspective: Lessons from the Luxembourg Income Study." Children and Youth Services Review 34(3):558-68. doi: https://doi.org/10.1016/j.childyouth.2011.10.016.

Hahn, Heather, Laudan Y. Aron, Cary Lou, Eleanor Pratt and Adaeze Okoli. 2017. "Why Does Cash Welfare Depend on Where You Live?". The Urban Institute.

Johnson, Martin. 2001. "The Impact of Social Diversity and Racial Attitudes on Social Welfare Policy." State Politics \& Policy Quarterly 1(1):27-49.

Katz, Michael B. 1990. The Undeserving Poor : From the War on Poverty to the War on Welfare. New York: Pantheon Books.

Korpi, Walter. 1983. The Democratic Class Struggle. London: Routledge \& Kegan Paul.

Krimmel, Katherine and Kelly Rader. 2017. "The Federal Spending Paradox: Economic SelfInterest and Symbolic Racism in Contemporary Fiscal Politics." American Politics Research:1532673X17701222. doi: 10.1177/1532673X17701222.

Lichter, Daniel, Zhenchao Qian and Martha Crowley. 2006. "Race and Poverty: Divergent Fortunes of America's Children?". Institute for Research on Poverty Focus Series 24(3).

Lohmann, Henning. 2009. "Welfare States, Labour Market Institutions and the Working Poor: A Comparative Analysis of 20 European Countries." European Sociological Review 25(4):489-504. doi: 10.1093/esr/jen064.

Lundquist, Erika, JoAnn Hsueh, Amy Lowenstein, Kristen Faucetta, Daniel Gubits, Charles Michalopoulos and Virginia Knox. 2014. "A Family-Strengthening Program for LowIncome Families: Final Impacts from the Supporting Healthy Marriage Evaluation." OPRE Report 2014-09A. 
Mettler, Suzanne. 1998. Dividing Citizens : Gender and Federalism in New Deal Public Policy. Ithaca, N.Y. ; London: Cornell University Press.

Meyer, Bruce D. and Nikolas Mittag. 2015. "Using Linked Survey and Administrative Data to Better Measure Income: Implications for Poverty, Program Effectiveness and Holes in the Safety Net." National Bureau of Economic Research Working Paper Series No. 21676. doi: 10.3386/w21676.

Meyers, Marcia K., Janet C. Gornick and Laura R. Peck. 2001. "Packaging Support for LowIncome Families: Policy Variation across the United States." Journal of Policy Analysis and Management 20(3):457-83. doi: 10.1002/pam.1003.

Moynihan, Daniel Patrick. 1965. "The Negro Family: The Case for National Action."

Newman, Katherine S. and Rourke L. O'Brien. 2011. Taxing the Poor : Doing Damage to the Truly Disadvantaged. Berkeley, Calif. ; London: University of California Press.

O'Brien, Rourke L. 2017. "Redistribution and the New Fiscal Sociology: Race and the Progressivity of State and Local Taxes." American Journal of Sociology 122(4):101549. doi: $10.1086 / 690118$.

Parolin, Zachary. 2019. "The Effect of Benefit Underreporting on Estimates of Poverty in the United States." Social Indicators Research (Online First). doi: 10.1007/s11205-01802053-0.

Patten, Eileen and Jens Manuel Krogstad. 2015. "Black Child Poverty Rate Holds Steady, Even as Other Groups See Declines." Pew Research Center.

Quadagno, Jill. 1998. "Race, Class, and Gender in the U.S. Welfare State

Nixon\&\#X2bc;S Failed Family Assistance Plan." Pp. 250-82 in Power Resource Theory and the Welfare State, A Critical Approach: University of Toronto Press.

Quadagno, Jill S. 1994. The Color of Welfare : How Racism Undermined the War on Poverty. New York: Oxford University Press.

Rainwater, Lee and Timothy M. Smeeding. 2003. Poor Kids in a Rich Country: America's Children in Comparative Perspective: Russell Sage Foundation.

Rector, Robert. 2012. "Marriage: America's Greatest Weapon against Child Poverty." The Heritage Foundation.

Richie, Clare. 2012. "Georgia Tanf Funds Sink to New Low." Georgia Budget \& Policy Institute.

Roberts, Dorothy E. 2004. "Welfare Reform and Economic Freedom: Low-Income Mothers' Decisions About Work at Home and in the Market." Institute for Policy Research Working Paper Series WP-04-02.

Sawhill, Isabel and Adam Thomas. 2002. "For Richer or for Poorer: Marriage as an Antipoverty Strategy." Journal of Policy Analysis and Management 21(4):587-99.

Sawhill, Isabel. 2014. Generation Unbound: Drifting into Sex and Parenthood without Marriage. Washington, D.C.: Brookings Institution Press.

Schott, Liz, LaDonna Pavetti and Ife Floyd. 2015. "How States Use Federal and State Funds under the Tanf Block Grant." Center on Budget \& Policy Priorities.

Schram, Sanford, Joe Soss and Richard C. Fording. 2003. Race and the Politics of Welfare Reform. Ann Arbor: University of Michigan Press.

Soss, J., S. F. Schram, T. P. Vartanian and E. O'Brien. 2001. "Setting the Terms of Relief: Explaining State Policy Choices in the Devolution Revolution." American Journal of Political Science 45(2):378-95. doi: Doi 10.2307/2669347.

Soss, J., Richard C. Fording and Sanford Schram. 2011. Disciplining the Poor : Neoliberal Paternalism and the Persistent Power of Race. Chicago: University of Chicago Press.

State of Mississippi. 2010. "Annual Report on Tanf Programs under 45 Cfr 265.9(B)."

Stephens, John D. 1979. The Transition from Capitalism to Socialism. London: Macmillan.

Taylor, Marylee C. 1998. "How White Attitudes Vary with the Racial Composition of Local 
Populations: Numbers Count." American Sociological Review 63(4):512-35. doi: $10.2307 / 2657265$.

Ziliak, James P. 2015. "Temporary Assistance for Needy Families." Cambridge, Mass.: National Bureau of Economic Research,. Retrieved.

(http://www.nber.org/papers/w21038). 


\section{Appendix A: Citations \& Details for Highlighted TANF Expenditures}

The table below provides more information on the TANF expenditures highlighted within this paper. Information is derived directly from state reports submitted to the U.S. Administration on Children \& Families and, when indicated, other state-provided materials. This is not an exhaustive list of non-core TANF spending allocations; it merely reflects those explicitly cited in this paper.

\begin{tabular}{|c|c|c|c|}
\hline Program Name & $\begin{array}{l}\text { State } \\
\text { (Year) }\end{array}$ & Details & Amount Spent \\
\hline Adoption Maintenance & $\mathrm{AZ}(2010)$ & $\mathrm{n} / \mathrm{a}$ & $\$ 4,371,645$ \\
\hline $\begin{array}{l}\text { Textbook Reimbursement } \\
\text { Program }\end{array}$ & IN (2010) & $\begin{array}{l}\text { Payment for the elementary and secondary } \\
\text { school textbook rental fee of low-income } \\
\text { families }\end{array}$ & $\$ 30,475,328$ \\
\hline Urgent Dental Care & KS (2010) & $\begin{array}{l}\text { The program first receiving TANF funds } \\
\text { in } 2010 \text {, during which } 135 \text { families were } \\
\text { served. }\end{array}$ & $\$ 18,322$ \\
\hline $\begin{array}{l}\text { Family Drug Court } \\
\text { Program }\end{array}$ & KY (2010) & Court-managed drug intervention program & $\$ 250,000$ \\
\hline United Way Programs & MI (2010) & Funding for United Way programs & $\$ 9,119,702$ \\
\hline $\begin{array}{l}\text { Private Foundation } \\
\text { Programs }\end{array}$ & MI (2010) & $\begin{array}{l}\text { Funding for Kellogg, Mott, and Skillman } \\
\text { foundations }\end{array}$ & $\$ 3,848,962$ \\
\hline Alternative to Abortion & PA (2010) & $\begin{array}{l}\text { Information and counseling that promote } \\
\text { childbirth instead of abortion and assists } \\
\text { pregnant women in their decisions } \\
\text { regarding adoption or parenting }\end{array}$ & Unspecified \\
\hline $\begin{array}{l}\text { Community-wide } \\
\text { abstinence-till-marriage } \\
\text { curriculum }\end{array}$ & MS (2010) & $\begin{array}{l}\text { Teaches the social, psychological and } \\
\text { physical effects of engaging in sexual } \\
\text { activities; curriculum to teach that } \\
\text { abstinence from sexual activity before } \\
\text { marriage, and fidelity within marriage is } \\
\text { the only certain way to avoid out-of- } \\
\text { wedlock pregnancy, sexually transmitted } \\
\text { diseases and related health problems; } \\
\text { curriculum to reinforce abstinence and } \\
\text { second-time abstinence }\end{array}$ & $\$ 1,474,879$ \\
\hline $\begin{array}{l}\text { Compulsive Gamblers } \\
\text { Program }\end{array}$ & CT (2009) & $\begin{array}{l}\text { The "Connecticut Partnership for } \\
\text { Responsible Gambling" was created by the } \\
\text { Connecticut Lottery Corporation. The } \\
\text { Partnership is designed to educate } \\
\text { consumers on problem gambling, underage } \\
\text { gambling, and to promote responsible play. } \\
\text { The Partnership also serves as a leading } \\
\text { resource for responsible gambling, } \\
\text { warning signs of problem gambling and } \\
\text { available treatment services. }\end{array}$ & Unspecified \\
\hline
\end{tabular}

\section{Sources:}

State of Arizona (2010). Annual Report on Temporary Assistance for Needy Families (TANF) Programs Under 45 CFR 265.9(b).

State of Indiana (2010). State TANF and MOE Annual Report 2010.

State of Kansas (2010). State TANF and MOE Annual Report 2010.

State of Kentucky (2010). Annual Report on Temporary Assistance for Needy Families (TANF) Programs 
Under 45 CFR 265.9(b).

State of Michigan (2010). State TANF and MOE Annual Report 2010.

State of Mississippi (2010). Annual Report On TANF Programs Under 45 CFR 265.9(b).

State of Pennsylvania (2010). Annual Reporting On TANF Programs Under 45 CFR 265.9(b)

State of Connecticut. (2009). Temporary Assistance for Needy Families (TANF) State Plan: Federal Fiscal Years October 1, 2008 Through September 30, 2011. Connecticut Department of Social Services. 
Appendix B: Data Sources \& Summary Statistics for State-Year Panel Data \& Household/Individual Data

State-Year Panel Data: 1997 to 2014 (Within-Between Random Effects Model)

\begin{tabular}{lrrrrr}
\hline Variable & Obs & Mean & Std. Dev. & \multicolumn{1}{l}{ Min } & \multicolumn{1}{l}{ Max } \\
\hline TANF \%Cash & 918 & 0.338 & 0.169 & 0.000 & 1 \\
\hline TANF \%Work & 918 & 0.315 & 0.155 & 0.000 & 0.766 \\
\hline TANF \%Family & 918 & 0.040 & 0.086 & 0.000 & 0.663 \\
\hline TANF \%Other & 918 & 0.202 & 0.160 & 0.000 & 0.809 \\
\hline GDP Per Capita & 918 & 47050 & 17715 & 28372 & 172917 \\
\hline Union Density & 918 & 0.116 & 0.056 & 0.020 & 0.269 \\
\hline Unemployment Rate & 918 & 0.057 & 0.020 & 0.023 & 0.137 \\
\hline Employment of Single-Mother & 918 & 0.721 & 0.064 & 0.512 & 0.910 \\
Families & & & & & \\
\hline Asian Share of Population & 918 & 0.040 & 0.075 & 0.003 & 0.702 \\
\hline Black Share of Population & 918 & 0.113 & 0.116 & 0.001 & 0.681 \\
\hline Hispanic Share of Population & 918 & 0.089 & 0.095 & 0.003 & 0.447 \\
\hline Share of Children in Single Parent & 918 & 0.208 & 0.054 & 0.100 & 0.514 \\
HH & & & & & \\
\hline Democrat Governor & 918 & 0.447 & 0.492 & 0.000 & 1.000 \\
\hline Democrat Share of State Legislature & 918 & 0.510 & 0.155 & 0.133 & 0.911 \\
\hline
\end{tabular}

\begin{tabular}{ll}
\hline Data Sources & \\
\hline Variable & Source \\
\hline TANF \%Cash & Center for Budget \& Policy Priorities (2015) \\
\hline TANF \%Work & Center for Budget \& Policy Priorities (2015) \\
\hline TANF \%Family & Center for Budget \& Policy Priorities (2015) \\
\hline TANF \%Other & Center for Budget \& Policy Priorities (2015) \\
\hline GDP Per Capita & $\begin{array}{l}\text { University of Kentucky Center on Poverty Research } \\
\text { (UKCPR) State Welfare Database (2016) }\end{array}$ \\
\hline Union Density & $\begin{array}{l}\text { Hirsch and Macpherson, (2003). "Union Membership } \\
\text { and Coverage Database from the Current Population }\end{array}$ \\
& $\begin{array}{l}\text { Survey: Note," Industrial and Labor Relations } \\
\text { Review, Vol. 56, No. 2. }\end{array}$ \\
\hline Unemployment Rate & U.S. Current Population Survey (three-year average) \\
\hline Employment of Single-Mother & U.S. Current Population Survey (three-year average) \\
Families & U.S. Current Population Survey (three-year average) \\
\hline Asian Share of Population & U.S. Current Population Survey (three-year average) \\
\hline Black Share of Population & U.S. Current Population Survey (three-year average) \\
\hline Hispanic Share of Population & U.S. Current Population Survey (three-year average) \\
\hline Share of Children in Single Parent & UKCPR State Welfare Database (2016) \\
\hline HH & UKCPR State Welfare Database (2016) \\
\hline Democrat Governor &
\end{tabular}




\begin{tabular}{|c|c|c|c|c|c|c|}
\hline & \multicolumn{6}{|c|}{$\begin{array}{l}\text { Individual/Household Data: 2012-2014 (Multi-Level Linear/Logistic Probability } \\
\text { Model) }\end{array}$} \\
\hline & Variable & Obs & Mean & $\begin{array}{l}\text { Std. } \\
\text { Dev. }\end{array}$ & Min & Max \\
\hline 1 & TANF \%Cash & 150,279 & 0.244 & 0.131 & 0.082 & 0.560 \\
\hline 2 & TANF \%Work & 150,279 & 0.318 & 0.167 & 0.020 & 0.701 \\
\hline 3 & TANF \%Family & 150,279 & 0.069 & 0.112 & 0.000 & 0.599 \\
\hline 4 & TANF \%Other & 150,279 & 0.275 & 0.205 & 0.026 & 0.753 \\
\hline 5 & GDP Per Capita & 150,279 & 49598 & 13834 & 31607 & 164161 \\
\hline 6 & Unemployment Rate & 150,279 & 0.069 & 0.017 & 0.028 & 0.112 \\
\hline 7 & Union Density & 150,279 & 0.110 & 0.056 & 0.020 & 0.246 \\
\hline 8 & State Minimum Wage $(\$ 2009)$ & 150,279 & 7.097 & 0.495 & 6.642 & 8.704 \\
\hline 9 & $\begin{array}{l}\text { State Supplement to EITC (\% } \\
\text { of Federal) }\end{array}$ & 150,279 & 0.067 & 0.106 & 0.000 & 0.040 \\
\hline 10 & $\begin{array}{l}\text { State Supplement to SSI } \\
(\$ 2009)\end{array}$ & 150,279 & 40.65 & 67.47 & 0.000 & 373.2 \\
\hline 11 & Black & 150,279 & 0.114 & 0.318 & 0.000 & 1.000 \\
\hline 12 & Hispanic & 150,279 & 0.218 & 0.413 & 0.000 & 1.000 \\
\hline 13 & Asian & 150,279 & 0.055 & 0.228 & 0.000 & 1.000 \\
\hline 14 & Other Race & 150,279 & 0.050 & 0.218 & 0.000 & 1.000 \\
\hline 15 & Non-Citizen Head & 150,279 & 0.119 & 0.323 & 0.000 & 1.000 \\
\hline 16 & Head Under 25 & 150,279 & 0.051 & 0.220 & 0.000 & 1.000 \\
\hline 17 & Head Age $25-34$ & 150,279 & 0.262 & 0.440 & 0.000 & 1.000 \\
\hline 18 & Head Age $54-65$ & 150,279 & 0.085 & 0.279 & 0.000 & 1.000 \\
\hline 19 & Head Age 66+ & 150,279 & 0.023 & 0.151 & 0.000 & 1.000 \\
\hline 20 & Head Less Than High School & 150,279 & 0.387 & 0.487 & 0.000 & 1.000 \\
\hline 21 & Head College or More & 150,279 & 0.321 & 0.467 & 0.000 & 1.000 \\
\hline 22 & Single Mother Household & 150,279 & 0.203 & 0.402 & 0.000 & 1.000 \\
\hline 23 & Single Father Household & 150,279 & 0.074 & 0.263 & 0.000 & 1.000 \\
\hline 24 & Jobless Household & 150,279 & 0.087 & 0.282 & 0.000 & 1.000 \\
\hline 25 & Dual-Earner Household & 150,279 & 0.523 & 0.499 & 0.000 & 1.000 \\
\hline 26 & \# of Children in Household & 150,279 & 2.423 & 1.244 & 1.000 & 12.000 \\
\hline 27 & \# of Age 66+ in Household & 150,279 & 0.066 & 0.296 & 0.000 & 7.000 \\
\hline
\end{tabular}

Data Sources:

1-4: Center on Budget \& Policy Priorities (2015)

5, 8-10: UKCPR State Welfare Database (2016)

6: U.S. Current Population Survey

7: Hirsch \& Macpherson (2003)

Individual-level variables (11-27) are created from individual- and household-level data available in the U.S.

Current Population Survey (CPS ASEC). 